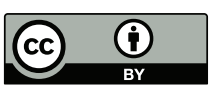

DOI 10.4467/12332135KRA.21.001.14680

\title{
Mateusz Mataniak
}

ORCID: 0000-0002-3311-5467

Uniwersytet Jagielloński w Krakowie

\section{Spory wśród mieszkańców Krakowa o służebności gruntowe miejskie (mur środkowy i prawo widoku). W świetle orzecznictwa sądów cywilnych Wolnego Miasta Krakowa (1815-1846)*}

\author{
Disputes among residents of Krakow regarding easements \\ of municipal property (central wall and right to a view). In light \\ of the case law of the civil courts in the Free City of Krakow (1815-1846)
}

SŁOWA KLUCZOWE: Wolne Miasto Kraków, Kodeks Napoleona, sądownictwo cywilne, Trybunał I Instancji, Sąd Apelacyjny, adwokaci, służebności

KEY WORDS: Free City of Krakow, Napoleonic Code, civil judiciary, Tribunal of First Instance, Court of Appeal, advocates, easements

\begin{abstract}
ABSTRAKT: W artykule przedstawiono rozstrzyganie - na drodze sądowej - sporów pomiędzy mieszkańcami Krakowa, w okresie Rzeczypospolitej Krakowskiej (1815-1846), które dotyczyły służebności gruntowych miejskich (mur środkowy, prawo widoku). We wprowadzeniu wskazano na rzymski rodowód służebności, ich najważniejsze podziały (służebności naturalne, ustawowe, umowne) oraz główne sposoby korzystania z nich. W dalszej części artykułu analizie poddano 14 spraw sądowych, toczących się przed sądami Wolnego Miasta Krakowa. Podstawę źródłową stanowiły wyroki Trybunału I Instancji, Sądu Apelacyjnego i Sądu III Instancji, przechowywane w Archiwum Narodowym w Krakowie (zespół Archiwum Wolnego Miasta Krakowa), a także akta z Archiwum Uniwersytetu Jagiellońskiego poświęcone działalności orzeczniczej Wydziału Prawa UJ w latach 1817-1833. W pracy znalazły się liczne dane w przedmiocie stosunków własnościowych w Krakowie. Artykuł stanowi przyczynek do dziejów stosowania prawa francuskiego
\end{abstract}

\footnotetext{
* Artykuł został przygotowany w ramach projektu badawczego „Prawo własności w orzecznictwie sądów Wolnego Miasta Krakowa. Z dziejów stosowania Kodeksu Napoleona", sfinansowanego przez Narodowe Centrum Nauki, nr umowy 2017/27/B/HS5/01308.
} 
(Kodeks Napoleona, Kodeks Procedury Cywilnej) na ziemiach polskich w pierwszej połowie XIX w.

\begin{abstract}
The article presents the settlement - in court - of disputes among the residents of Krakow, during the period of the Republic of Krakow (1815-1846), which concerned the easements of municipal property (central wall, right to a view). The introduction shows easements based on Roman rules, their most important divisions (natural, legal and contractual) as well as the ways of using them. Later in the article, there is an analysis of 14 court cases from the Free City of Krakow. The basis for this are the verdicts of the Tribunal of First Instance, the Court of Appeal and the Court of Third Instance, stored in the National Archives in Krakow (Archive of the Free City of Krakow), as well as records from the Jagiellonian University Archives, dedicated to the judicial activities of the Faculty of Law of Jagiellonian University, during the years 1817-1833. The work contains a great deal of information concerning property relations in Krakow. The article represents a contribution to the usage of French law (Napoleonic Code, Code of Civil Procedure ) in Polish land during the first half of the $19^{\text {th }}$ century.
\end{abstract}

Przedmiotem niniejszego opracowania są spory cywilne pomiędzy mieszkańcami Krakowa toczące się w okresie Rzeczypospolitej Krakowskiej (1815-1846), dotyczące dwóch służebności gruntowych miejskich: muru środkowego oraz prawa widoku. Do podjęcia badań w tym zakresie zachęca obfitość materiałów źródłowych należących do zasobu Archiwum Narodowego w Krakowie. Chodzi przede wszystkim o księgi sądowe powstałe w toku działalności orzeczniczej Trybunału I Instancji, Sądu Apelacyjnego oraz Sądu III Instancji, stanowiące część obszernego zespołu Archiwum Wolnego Miasta Krakowa ${ }^{1}$.

Tytułem wprowadzenia trzeba powiedzieć, że podstawę prawną dla omawianych rozstrzygnięć sądowych stanowił uchwalony w 1804 r. Kodeks Napoleona (dalej: KN) - powszechnie uważany za arcydzieło sztuki legislatorskiej. Został on wprowadzony w Krakowie w 1810 r., kiedy miasto było „stolicą" jednego z departamentów pogalicyjskich; zachował moc obowią-

${ }^{1}$ Szerzej zob. Stanisława Pańków, Archiwum Wolnego Miasta Krakowa, „Archeion" 1954, R. 22, s. 103-128. Istotną rolę odegrały także zasoby Archiwum Uniwersytetu Jagiellońskiego („Akta Wydziału Profesorów i Doktorów Prawa 1817-1833”). 
zującą w okresie Wolnego Miasta Krakowa i jeszcze dłużej - aż do 1855 r. ${ }^{2}$ Problematyce służebności poświęcony został jego Tytuł IV „O służebnościach, albo służbach gruntowych” (art. 637-710), w ramach Księgi II „O majątkach i różnych odmianach własności”3.

Generalnie rzecz biorąc, na gruncie kodeksowym służebności stanowiły jedno z dwóch, obok własności, głównych praw rzeczowych; zarazem jedno z dwóch, obok użytkowania, praw rzeczowych ograniczonych. Liczba przepisów dotyczących służebności była znacząca i dość silnie rozbudowana, a przy tym kazuistyczna, co świadczyło o dużej wadze, jaką twórcy kodeksu przywiązywali do tej tematyki. Warto wspomnieć o rzymskim rodowodzie służebności (servitutes), należących do tzw. praw na rzeczy cudzej (iura in re aliena). Juryści antyczni, których dorobek jest niekwestionowany w europejskiej nauce prawa, nie tylko stworzyli definicję służebności, ale także wyprowadzili ich klasyfikacje, określając przy okazji rządzące nimi reguły ${ }^{4}$.

W ujęciu definicyjnym za służebność należy uważać prawo obciążające cudzy grunt, polegające na zwiększeniu użyteczności lub przymnożeniu po-

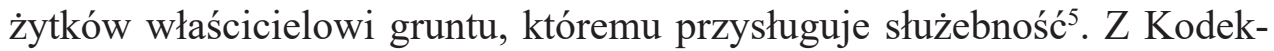

${ }^{2}$ Stanisław Grodziski, Wplywy ,Code civil” oraz innych kodyfikacji napoleońskich na ziemiach polskich, cz.1, „Czasopismo Prawno-Historyczne” 2005, t. 57, z. 2, s. 61-67; Dorota Malec, Wpływy „Code Civil” oraz innych kodyfikacji napoleońskich na ziemiach polskich, cz. 2, „Czasopismo Prawno-Historyczne” 2005, t. 57, z. 2, s. 69-87; Wacław Uruszczak, Prawo francuskie w Rzeczypospolitej Krakowskiej (1815-1846), [w:] Szkice z dziejów ustroju i prawa, red. Marcin Kwiecień, Marian Małecki, Kraków 1997, s. 91-99; Lesław Pauli, Prawa obce w Rzeczypospolitej Krakowskiej, „Zeszyty Naukowe Uniwersytetu Jagiellońskiego" 1982, t. 625, Prace Prawnicze, z. 97, s. 145-147.

${ }^{3}$ Tytuł IV składał się z trzech działów podzielonych na oddziały i artykuły. Korzystałem z pierwszego tłumaczenia kodeksu autorstwa Franciszka Ksawerego Szaniawskiego (1810), które było też dostępne sędziom krakowskim. Ostatnio tekst opublikowano jako aneks [do:] Katarzyna Sójka-Zielińska, Kodeks Napoleona. Historia i współczesność, Warszawa 2008, s. 295-585. Zob. Anna Rosner, Pierwsze polskie ttumaczenia Kodeksu Napoleona, [w:] ibidem, s. 271-294.

${ }^{4}$ Nic więc dziwnego, że problematyka służebności ma swoje miejsce we wszystkich podręcznikowych ujęciach tej dyscypliny, Wacław Osuchowski, Rzymskie prawo prywatne. Zarys wykładu, Warszawa 1988, s. 284-292; Wiesław Litewski, Rzymskie prawo prywatne, Warszawa 1999, s. 221-224; Marek Kuryłowicz, Adam Wiliński, Rzymskie prawo prywatne. Zarys wykładu, Zakamycze 2002, s. 239-243.

${ }^{5}$ Karol Hube, Prawo cywilne obowiąujące w Guberniach Królestwa Polskiego, Warszawa 1877, s. 333. 
su Napoleona zniknęły służebności osobiste, co było rezultatem likwidacji ostatnich reliktów systemu feudalnego w dobie Wielkiej Rewolucji Francuskiej. Utrzymały się służebności gruntowe, w zależności od miejsca położenia określane mianem wiejskich i miejskich. Wśród tych ostatnich, w ślad za jurysprudencją rzymską, można było wskazać prawo: a) ścieku wody deszczowej na grunt sąsiada (servitus stillicidii); b) wbudowania belki z własnego budynku w mur budowli sąsiada (servitus tigni immittendi); c) oparcia budynku o ścianę budowli sąsiada (servitus oneris ferend); d) otwarcia okna nad gruntem sąsiada (servitus luminum) ${ }^{6}$.

Służebności gruntowe powinny odpowiadać kilku wymogom ogólnym. Przede wszystkim muszą polegać na zaniechaniu (non facere), jak w przypadku służebności miejskich, lub znoszeniu (pati) (służebności wiejskie). Wyrażała to zasada: servitus in faciendo consistere nequit. Po drugie, grunt służebny musiał być użyteczny dla gruntu panującego, a ściśle - dla jego każdoczesnego właściciela ${ }^{7}$.

Ze względu na sposób powstawania KN wyróżniał służebności: a) naturalne, będące skutkiem niekorzystnego położenia nieruchomości (,,pochodzące z położenia miejsc", art. 640-648); b) ustawowe, wynikające z obowiązków nałożonych przez prawo (art. 649-685); c) umowne (,ustanowione przez czyn człowieka”, art. 686-689). Niektórzy przedstawiciele doktryny francuskiej zwracali uwagę, że wyłącznie służebności umowne zasługują na miano służebności sensu stricte, gdyż jako jedyne stanowią ciężar dla nieruchomości obciążonej i korzyść dla władnącej.

Analiza akt sądowych dotyczących 14 spraw, które trafiły przynajmniej przed oblicze Sądu Apelacyjnego, przekonuje, że krakowianie toczyli spory odnoszące się do „muru środkowego” (art. 653-673 KN), prawa widoku (art. 675-680 KN) i ścieku z dachów (art. $681 \mathrm{KN}$ ), co świadczy o ich istotnej roli w kształtowaniu relacji sąsiedzkich tamtego okresu'. Sprawy odby-

${ }^{6}$ W. Litewski, Rzymskie..., s. 222.

${ }^{7}$ Ibidem, s. 222-223. Niemożliwa była służebność na własnym gruncie; służebność nie mogła zostać zbyta bez gruntu panującego; służebności były zasadniczo niepodzielne; należało je wykonywać oględnie.

${ }^{8} \mathrm{Z}$ tego względu kategorie z pkt. a-b można uważać jedynie za służebności sensu largo, Jean Joseph Delsol, Zasady Kodeksu Napoleona w zwiazku z nauka i jurysprudencja przedstawione, t. 1, Warszawa 1873, s. 450-451. „Tylko służebności ustanowione przez czyn człowieka naruszają rzeczywiście wolność majątkową".

${ }^{9} \mathrm{~W}$ artykule pominięto sprawy o mniejszej randze, które zakończyły się w sądzie pokoju lub Trybunale I Instancji. Ogólną charakterystykę akt sądowych z tego okresu zob. Piotr 
wały się przed organami wymiaru sprawiedliwości, czyli, w świetle trzech Konstytucji Wolnego Miasta (z 3 maja 1815, 11 września 1818 i 29 lipca 1833 r.): sądami pokoju (,urzędy pojednawcze”), Trybunałem I Instancji oraz Sądem Apelacyjnym. W ramach trójszczeblowej struktury sądownictwa funkcjonował też Sąd Ostatniej Instancji, będący w istocie Sądem Apelacyjnym w rozszerzonym składzie ${ }^{10}$.

W opracowaniu omówiono sprawy, w których najważniejszą rolę odgrywała kwestia muru środkowego, a także kazusy poświęcone służebnościom widoku i światła. Aby skrótowo wyjaśnić, na czym zasadza się instytucja muru środkowego, należy powiedzieć, że polega ona na wspólnym korzystaniu przez sąsiadów z muru lub innego ogrodzenia oddzielającego dwa budynki - aż do linii dachu (,do wierzchołka budynku niższego”); mur może także rozdzielać podwórza, ogrody itd. Współwłasność muru odnosi się do całej jego grubości, z czego wynikają dalsze konsekwencje dla współwłaścicieli, w tym obowiązek jego remontowania i przerabiania w razie potrzeby (,naprawa i przebudowywanie”). Uwolnienie się od tych obowiązków jest możliwe jedynie w drodze „zrzeczenia się prawa środkowości”, co nie przysługuje właścicielowi budynku podpieranego przez mur środkowy. Z faktu ,środkowości” wypływały liczne korzyści, w tym możliwość stawiania przybudówek, wpuszczania belek, a także podwyższania muru na swój koszt i z poszanowaniem interesów sąsiada; należało się przy tym liczyć z koniecznością wynagrodzenia wyrządzonych w murze szkód (art. 653, 655-659 KN). Wystawienie muru środkowego bądź uczynienie takim muru już istniejącego, a to w drodze nabycia „środkowości” (art. 660-661 $\mathrm{KN}$ ), łączyło się zwykle z korzystaniem ze służebności widoku lub światła. Swego rodzaju ,przeciwieństwem” muru środkowego był tzw. mur nieśrodkowy, stanowiący wyłączną własność jednego z sąsiadów, co rodziło określone konsekwencje prawne ${ }^{11}$.

Z. Pomianowski, Rozwód w XIX wieku na centralnych ziemiach polskich. Polityka stosowania Kodeksu Napoleona w latach 1808-1852, Warszawa 2018, s. 16-19.

${ }^{10}$ Najnowsze ujęcie organizacji sądownictwa zob. Mateusz Mataniak, Urzędnicy sadowi Wolnego Miasta Krakowa (1815-1846) na tle zasad organizacji jego sadownictwa. Zarys problematyki, [w:] Dzieje biurokracji, t. 9, red. Artur Górak, Julia Kukarina, Jacek Legieć, Lublin 2019, s. 65-71; idem, Rada Administracyjna Miasta Krakowa i Jego Okręgu (1846-1853), Biblioteka Krakowska nr 165, Kraków 2019, s. 348-356.

${ }^{11}$ W KN wskazano też na „znaki nieśrodkowości”, czyli zespół domniemań przemawiających na rzecz własności tylko jednego z sąsiadów. 
Tematyka służebności cieszyła się dużym zainteresowaniem doktryny i orzecznictwa francuskiego w zasadzie od momentu wejścia w życie Kodeksu Napoleona ${ }^{12}$. Warto w tym miejscu wskazać autorów książek dostępnych w Bibliotece Jagiellońskiej, znanych prawdopodobnie krakowskim sędziom i adwokatom ${ }^{13}$. Osobną i bardzo obszerną pracę poświęcił służebnościom słynny prawnik Jean Charles Demolombe ${ }^{14}$.

\section{Sprawa Borkowskich przeciwko Wermuthowi}

W dniu 10 września 1787 r. doszło do zawarcia transakcji, jakich zapewne bez liku dałoby się odnotować w dziejach Krakowa. Za kwotę 3000 złp Zofia Sokołowska sprzedała małżonkom Błażejowi i Katarzynie Gaudzińskim kamienicę w chrześcijańskiej części Kazimierza przy ulicy Żydowskiej, oznaczoną L. 100 (obecnie: ul. Józefa 6), usytuowaną pomiędzy kamienicą Wójcikiewiczów a drewnianym domem Borkowskich ${ }^{15}$. W $1802 \mathrm{r}$. po śmierci Gaudzińskiej kamienicę zlicytowano za 8400 złp na rzecz Józefa Fiszera, ale ponieważ finalnie nie uiścił on wymaganej kwoty, w 1818 r. przeprowadzono jeszcze jedno „zlicytowanie sądowe”, którego zwycięzcą okazał się Markus Wohl, oferujący 12022 złp. Rok później sprzedał on budynek trudniącemu się wyszynkiem alkoholu Izaakowi Wermuthowi - za 18900 złp. W 1820 r. nowy właściciel zapragnął uzyskać widok („otwarcie okien”) na posiadłość sąsiadów - Stefana i Salomei Borkowskich, zamieszkałych pod L. 101 (obecnie: ul. Józefa 8), co mógł osiągnąć poprzez wybicie cegieł w dwóch zamurowanych niegdyś oknach swojej kamienicy. W związku z tym, ,za przywołaniem” właścicieli obu domów zebrała się komisja policyjno-budowlana, w gronie której znaleźli się urzędnicy Urzędu Budownictwa oraz Urzędu Policji Pośredniej. Po kilkugodzinnych oględzinach (,obejrzeniu ścian”) komisja zgodziła się na „wybicie cegieł”, co na-

${ }^{12}$ Zob. J. J. Delsol, Zasady...; Charles Aubry, Frédéric Charles Rau, Cours de droit civil français d'après la méthode de Zachariae, t. 2, Paris 1935.

${ }^{13}$ Claude-Étienne Delvincourt, Cours de code civil, t. 1, Paris 1824; Charles Bonaventure Toullier, Droit civil français suivant l'ordre du Code Napoléon, ouvrage dans lequel on a tâché de réunir la théorie à la pratique, t. 3, Bruxelles 1824; Victor Napoléon Marcadé, Cours élémentaire de droit civile, t. 2, Paris 1850.

${ }^{14}$ Jean Charles Demolombe, Cours de Code Napoléon: Traité des servitudes ou services fonciers, t. 1-2, Paris 1855.

${ }^{15}$ Plan miasta Krakowa Ignacego Enderle z lat (1802-1805) 1807-1808 tak zwany Senacki wraz z wykazem realności miasta z początku XIX wieku, wyd. Henryk Münch, Kraków 1959, s. 25 (oraz sekcja 57 - plan z identyfikacją adresów). 
stępnie zatwierdził Wydział Policji w Senacie Rządzącym. Zaprotestowali przeciwko temu Borkowscy, wnosząc do sądu pokoju skargę posesoryjną (in possesorio), w której domagali się utrzymania w spokojnym posiadaniu nieruchomości ${ }^{16}$.

W reakcji na poczynania sąsiadów Wermuth zażądał przysądzenia mu wyłącznej własności muru, który stałby się tym samym murem „nieśrodkowym”. Korzyścią płynącą z tego tytułu była możliwość ,robienia otworów dla widoku, lub okna z kratą żelazną, i z osadą ze szkieł, która się nie otwiera" (art. $676 \mathrm{KN})^{17}$. Żądanie Wermutha Borkowscy przyjęli z oburzeniem. Byli przekonani, że skutecznie zasiedzieli współwłasność muru, jako że do ich okresu posiadania należało doliczyć także czas korzystania z muru przez poprzednich właścicieli domu pod L. 101. Wynikająca zaś z tego faktu ,środkowość" uniemożliwiała Wermuthowi wybijanie okien bądź innych otworów bez ich zgody jako sąsiadów (art. $675 \mathrm{KN}$ ). Na tym nie koniec. Wobec 30-letniego niewykonywania służebności, przejawiającego się w „nieużywaniu prawa otworu”, Wermuth miał w ogóle utracić ową służebność (art. $706 \mathrm{KN}$ ), co w oczywisty sposób niweczyło jego roszczenie ${ }^{18}$.

Do argumentacji Borkowskich, w tym ich roszczenia posesoryjnego, przychylił się sąd pokoju, który wyrokiem z 17 sierpnia 1820 r. nakazał Wermuthowi bezzwłoczne, w ciągu 24 godzin, zamurowanie wybitych już okien. Sąd stwierdził, że do urządzenia okna w murze środkowym doszło „bez zezwolenia sąsiada”, co stało w sprzeczności ze wspomnianym art. 675 KN. Przyznał też obu sąsiadom „wspólność” muru. Rozpatrujący odwołanie Sąd Apelacyjny wyrokiem z 29 sierpnia 1820 r. zatwierdził wyrok I instancji, ale tylko w części dotyczącej kwestii posesoryjnej, czyli zasklepienia

${ }^{16}$ ANK, Archiwum Wolnego Miasta Krakowa, sygn. 29/200/1723, s. 445-446 („Notta Oppozycyjna ze strony Starozakonnego Izaaka Wermuth przeciwko Stefanowi i Salomei Borkowskim małżonkom"). W tym przypadku spokojne posiadanie nieruchomości sprowadzało się do tego, że Wermuth musiał zaniechać ingerencji na własnej nieruchomości (wybicia okna) jako właściciel gruntu obciążonego (służebnego).

${ }^{17}$ Ibidem, s. 446-447; uchwała Wydziału Policji z 30 lipca 1820 r. Takie rozwiązanie było jednym z przejawów służebności widoku.

${ }^{18}$ ANK, Archiwum Wolnego Miasta Krakowa, sygn. 29/200/1660, s. 179-181 („Obrona ze strony Borkowskiej przeciwko Wermuthowi”). Na służebność okna można spojrzeć w dwojaki sposób: jako możliwość patrzenia na posiadłość sąsiada - co ten musi znosić; ewentualnie jako zabronienie mu wznoszenia konstrukcji powyżej pewnej wysokości, które uniemożliwiałyby ów widok. 
okien; co do samej dopuszczalności ich wybicia odesłał strony do ustaleń władz policyjnych ${ }^{19}$.

Linia argumentacji Józefa Jankowskiego, adwokata Wermutha, opierała się na twierdzeniu, że prawo widoku egzystowało przez cały okres lat 1787-1819, przy czym nie miała znaczenia czterokrotna zmiana właściciela kamienicy. Prawo to jest bowiem służebnością gruntową, a więc przysługuje każdemu kolejnemu właścicielowi nieruchomości; relewantna prawnie miała być także przejściowa niedostępność jednego z okien na drugim piętrze spowodowana pracami remontowymi. Adwokat dodawał, że skoro Borkowscy „od długiego czasu” (tj. od chwili zakupu domu) tolerowali obciążenie swojej nieruchomości służebnością, to nie mogli mu jej teraz odmawiać (zakazać „otwarcia nowych okien, w równej lub wyższej linii z dawniejszymi”). Przeciwko środkowości „od fundamentów aż do teraźniejszej wysokości” przemawiał także fakt niezgłoszenia wspólności muru przy kolejnych licytacjach domu ${ }^{20}$. Adwokat Wermutha przyznawał rację przeciwnikom jedynie $\mathrm{w}$ tym, że służebność widoku należy uważać za „ciągłą i widoczną" (art. 688-689 KN) ${ }^{21}$, a więc taką, która na mocy art. $690 \mathrm{KN}$ może być nabyta w drodze zasiedzenia (,preskrypcji”) 22. Jankowski przedkładał też dowody pisemne, które miały przeczyć zasiedzeniu. Był to m.in. kwit wystawiony przez ks. Antoniego Zaćwilichowskiego, prokuratora reprezentującego interesy zgromadzenia Kanoników, który stano-

${ }^{19}$ Ibidem, sygn. 29/200/1723, s. 448-450 (,Notta Oppozycyjna ze strony Starozakonnego Izaaka Wermuth przeciwko Stefanowi i Salomei Borkowskim małżonkom”). Sąd Apelacyjny trafnie zwrócił uwagę na niedopuszczalność badania przez sądy pokoju kwestii petytoryjnych.

${ }^{20}$ Ibidem, s. 449-450. Wermuth przypominał, że właściciele nieruchomości, którzy wybudowali kamienicę, nabyli od zgromadzenia kanoników regularnych (lateraneńskich) przy kościele Bożego Ciała jedynie pusty plac; Borkowscy zaś nie brali w tym w ogóle udziału.

${ }^{21}$ Art. 688 ust. 1: „Służebności są albo ciągłe, albo przerywane. Ciągłe służebności są te, których użycie jest lub być może ciągłe, choć nie potrzeba, aby człowiek przykładał się do nich rzeczywiście. Takimi są zbiegi wód, ścieki, widoki i inne tego gatunku”. Art. 689 ust. 1: „Służebności widoczne są te, które się same okazują przez zewnętrzne dzieła, jako to: brama, okno, kanał".

${ }^{22}$ Art. 690: „Służebności ciągłe i widoczne nabywanymi bywają albo przez tytuł albo przez trzydziestoletnie posiadanie”. Art. 707: „Czas trzydziestoletni zaczyna swój bieg podług różnych gatunków służebności, albo od dnia, w którym ustało używanie służebności jeżeli idzie o służebności przerywane, albo od dnia, w którym uczyniony był akt przeciwny służebności, gdy idzie o służebności ciągłe”. 
wił dowód, że poprzednicy Borkowskich ,nabyli tylko plac pusty, ale nie wspólność muru". Z drugiej strony kwestionował przydatność dokumentów przedkładanych przez przeciwników, mających przemawiać za wspólnością muru: opinię biegłych, protokół sądowej „rewizji okien” z 1783 r., a także wyrok Magistratu kazimierskiego z 1784 r. Jedyny adekwatny dokument, na który się powoływali, czyli dekret wielkorządowy, został wydany 7 listopada 1793 r., a tym samym w 1819 r. nie upłynęło 30 lat „spokojnego posiadania"23.

Argumenty Wermutha Borkowscy starali się zbijać w odpowiedzi odczytanej na forum Sądu Apelacyjnego. Wskazywali na domniemanie kodeksowe z art. $653 \mathrm{KN}$, że każdy mur sąsiedzki jest co do zasady wspólny (przemawia za tym chociażby interes publiczny), a to właśnie na twierdzącym przeciwnie, czyli Wermuthcie, spoczywa obowiązek wykazania, że jest inaczej (maksyma ei incumbit probatio qui dicit, non qui negat). Wermuth mógł to uczynić przez powołanie się na jakiś tytuł prawny, np. umowę albo „znaki przeciwne” świadczące o „nieśrodkowości” - czego jednak nie dopełnił. Odnośnie do zarzutu niezgłoszenia wspólności muru odpowiadali, że przy licytacji kamienicy wzywano jedynie ewentualnych wierzycieli hipotecznych; w przypadku współwłaścicieli muru nie było takiej konieczności, gdyż nie stwierdzono jakiegokolwiek zagrożenia dla trwałości konstrukcji; zarzut uchylenia wyroku Magistratu (1784) wyrokiem wielkorządowym (1793) był przynajmniej częściowo nietrafny, gdyż dotyczył on w istocie dwóch odrębnych kwestii: spokojnego posiadania, a także zwrotu kosztów reparacji budynku. Borkowscy dowodzili, że protokół rewizji sądowej (1783) został zatwierdzony, a więc funkcjonuje jako pełnoprawny dokument urzędowy, a tym samym - pełnowartościowy dowód, którego wiarygodność można było podważać jedynie podejrzeniem fałszerstwa - czego Wermuth nie czynił (niedopuszczalne było występowanie „przeciwko osnowie”); kwit prokuratora nie mógł być przeciwdowodem dla protokołu rewizji i wyroku Magistratu jako dowód zbyt błahy ${ }^{24}$.

${ }^{23}$ ANK, Archiwum Wolnego Miasta Krakowa, sygn. 29/200/1723, s. 449-455 („Notta Oppozycyjna ze strony Starozakonnego Izaaka Wermuth przeciwko Stefanowi i Salomei Borkowskim małżonkom"). Rewizja sądowa nie mogła być dowodem, gdyż nie podpisały jej wszystkie wymagane osoby. Dodatkowym argumentem była niedopuszczalność ,przedawniania przeciwko tytułowi”.

${ }^{24}$ Ibidem, s. 457-458 (,Odpowiedź ze strony Borkowskich przeciwko Wermuthom”); ibidem, sygn. 29/200/1660, s. 179-181 („Obrona ze strony Borkowskiej przeciwko Wer- 
Trybunał zasadniczo przychylił się do argumentacji Borkowskich, uznając, że swoje prawa wykazali dokumentacją z lat 1783-1784 i w rezultacie 30-letniego korzystania zasiedzieli („odziedziczyli”) po poprzednich właścicielach wspólność muru. W tym samym czasie Wermuth nie używał prawa „otworu okien zamurowanych”, wobec czego utracił je na podstawie art. $706 \mathrm{KN}^{25}$. Dopuścił się też zakazanych art. $702 \mathrm{KN}$,odmian, które by powiększały obciążenia gruntu służebnego”, co stało w sprzeczności z rzymską maksymą, że służebności należy wykonywać oględnie (servitutibus civiliter utendum est ${ }^{26}$.

Wyrok Trybunału podtrzymał w całości Sąd Apelacyjny, wydając dwa wyroki: zaoczny i „oczny”, i stwierdzając całkowitą „niegruntowność zasad oppozycji" Wermutha ${ }^{27}$. Niezadowolony z takiego obrotu spraw Wermuth skorzystał z prawa wniesienia odwołania do Wydziału Profesorów i Doktorów Prawa Uniwersytetu Jagiellońskiego, który na podstawie art. 15 Konstytucji z 1815 r. badał - tylko na wniosek stron - jednozgodne wyroki dwóch instancji pod kątem naruszenia prawa materialnego bądź formalnego (procesowego). Jeżeli uchwała Wydziału była pozytywna, strona mogła wnieść skargę kasacyjną do Sądu III (Ostatniej) Instancji ${ }^{28}$.

muthowi”). Wątpliwości dotyczyły też kwestii, czy ustalenia „komisji w linii politycznej” mogą być dowodem wspólności muru - prawo przewidywało w tym przypadku ,formy pod nieważnością” w postaci relacji biegłych i „naocznego przekonania się”.

${ }^{25}$ Art. 706: „Ginie służebność przez trzydziestoletnie jej nieużywanie”. W tym kontekście sąd wskazał też art. 2229 KN („Ażeby mieć możność do nabycia przedawnienia, potrzeba mieć posiadanie ciągłe i nieprzerywane, spokojne, jawne, niedwuznaczne i pod tytułem właściciela”) i art. 2262 KN (,Wszelkie sprawy tak rzeczowe, jak osobiste, podlegają przedawnieniu ciągiem lat trzydziestu, i przytaczający takie przedawnienie obowiązanym nie jest okazywać na to tytuł, ani nie można stawiać przeciw niemu wyjątku, wynikającego ze złej wiary").

${ }^{26}$ ANK, Archiwum Wolnego Miasta Krakowa, sygn. 29/200/1723, s. 449-450 („Notta Oppozycyjna ze strony Starozakonnego Izaaka Wermuth przeciwko Stefanowi i Salomei Borkowskim małżonkom" - omówienie wyroku Trybunału I Instancji z 26 stycznia 1821 r.). Ze względu na „nieprzyzwoitość czynności” sąd skazał Wermutha na koszty sądowe.

${ }^{27}$ Ibidem, s. 441-442 (wyroki Sądu Apelacyjnego: z 7 października 1823 r.; z 10 października 1822 r. - zaoczny).

${ }^{28}$ Kasację można było wnieść także od dwóch wyroków różnobrzmiących bez opinii Wydziału. O działalności opiniodawczej Wydziału zob. Andrzej Dziadzio, Udział Wydziału Prawa Uniwersytetu Jagiellońskiego w stosowaniu Code civil w Wolnym Mieście Krakowie (1815-1833), [w:] Miasto i państwo na przestrzeni dziejów. Studium historyczno-prawne. Księga Jubileuszowa z okazji czterdziestopięciolecia pracy naukowej oraz 70. urodzin Profesora Tadeusza Maciejewskiego, red. Michał Gałędek, Warszawa 
Profesorowie stwierdzili, że rozstrzygnięcie sprawy zależy od odpowiedzi na pytanie, czy przedłożone dokumenty (1783-1784) stanowią dowody świadczące o wspólności muru oraz czy doszło do zasiedzenia służebności wskutek 30-letniego posiadania. Analizując sprawę, członkowie fakultetu prawnego uznali, że rewizja sądowa (1783) jako ,jednostronnie uskuteczniona" takiego dowodu nie stanowi; podobnie rzecz się miała z wyrokiem Magistratu (1784), który został uchylony dekretem wielkorządowym (1793); niezgłoszenie wspólności muru przy okazji licytacji było poważnym zaniedbaniem. A ponieważ naruszono jeszcze inne przepisy KN (art. 544, 690, 1315, 2240, 2229, 2268), na co nie zwróciły uwagi ani strony postępowania, ani sądy, w konkluzji Wydział stwierdził, iż Borkowscy ,ani przez tytuł, ani przez posiadanie 30-letnie prawa do wspólności muru nie nabyli”, dając tym samym miejsce odwołaniu do sądu kasacyjnego ${ }^{29}$.

Co ciekawe, ten ostatni nie podzielił uwag Wydziału, dwukrotnie utrzymując $\mathrm{w}$ mocy rozstrzygnięcia niższych instancji ${ }^{30}$. Należy odnotować, że swoją argumentację konsekwentnie powtórzyły też strony procesu ${ }^{31}$.

\section{Sprawa Wermuthów przeciwko Gajdzińskim}

Wespół z małżonką Sarą Izaak Wermuth był stroną postępowania przeciwko jeszcze innym sąsiadom - Józefowi i Katarzynie Gajdzińskim, zamieszkałym w kamienicy pod L. 99 (obecnie ul. Józefa 4) 32. Pomiędzy należącymi do obu małżeństw budynkami znajdował się mur, który zgodnie

2020, s. 185-200; idem, Opinie profesorów i doktorów Wydziatu Prawa Uniwersytetu Jagiellońskiego jako źródło do badań nad stosowaniem Kodeksu Napoleona w Wolnym Mieście Krakowie, „Krakowskie Studia z Historii Państwa i Prawa” 2020, t. 13, z. 3, s. 303-319.

${ }^{29}$ Archiwum Uniwersytetu Jagiellońskiego, sygn. WP I 58, s. 199-201 (opinia Wydziału Prawa UJ z 19 listopada 1823 r.). Generalnie Wydział przychylił się do argumentacji Wermutha - wyjątkiem było uznanie, że kwit prokuratorski dowodzi jedynie nabycia pustego placu. Opinię wydali: Mikołaj Hoszowski, Augustyn Boduszyński, Feliks Słotwiński, ks. Mateusz Dubiecki i Antoni Matakiewicz.

${ }^{30}$ ANK, Archiwum Wolnego Miasta Krakowa, sygn. 29/200/1660, s. 69-70 (wyrok Sądu III Instancji z 4 marca 1824 r.); ibidem, s. 171-172 (wyrok Sądu III Instancji z 22 kwietnia 1824 r.). Generalnie Sąd przychylił się do argumentacji Borkowskich.

${ }^{31}$ Ibidem, s. 175-176 (,Nota Oppozycyjna ze strony Starozak. Jakuba Wermuth przeciwko Salomei Borkowskiej wdowie”); ibidem, s. 179-181 („Obrona ze strony Borkowskiej przeciwko Wermuthowi").

${ }^{32}$ Plan miasta Krakowa..., s. 25 (oraz sekcja 57 - plan z identyfikacją adresów). 
z art. $653 \mathrm{KN}$ aż do szczytu niższego z nich (w tym przypadku był nim dom Wermuthów) miał być użytkowany w formie współwłasności ${ }^{33}$. Powyżej tego poziomu stanowił własność Gajdzińskich, którzy zgodzili się na jego udostępnienie Wermuthom „w razie potrzeby” i za opłatą połowy wartości. Zarzewiem konfliktu stały się prace remontowo-budowlane prowadzone przez Gajdzińskiego na podstawie zawartej w formie aktu notarialnego umowy z Wermuthem. Warto dodać, że korzystając ze sztandarowej zasady KN, czyli swobody umów (słynny art. 1134: „Umowy prawnie ułożone zastępują miejsce prawa dla tych, którzy je uczynili”), strony istotnie zmodyfikowały przepisy kodeksu w zakresie odpowiedzialności za wyrządzone szkody ${ }^{34}$.

W omawianym kazusie znalazł zastosowanie art. $658 \mathrm{KN}$ dopuszczający przebudowę (,,podniesienie”) muru środkowego przez jednego z właścicieli, ale własnym kosztem, z obowiązkiem konserwacji podwyższonej części oraz wynagrodzenia sąsiadowi wszelkich uciążliwości. Można też dostrzec art. $659 \mathrm{KN}$, który nakładał obowiązek przebudowy (a w skrajnych przypadkach wystawienia na nowo) muru środkowego - na tego spośród współwłaścicieli, który w rezultacie podwyższenia doprowadził do uszkodzenia konstrukcji. Wchodząc w szczegóły, można powiedzieć, że wskutek poczynań Gajdzińskiego uszkodzeniu uległy dwa fragmenty muru. Po pierwsze, odcinek oznaczony na planie budowy linią G-H, w którym Gajdziński zrobił nadbudówki i tym samym spowodował „dezolacje” tak poważne, że jedynym wyjściem była natychmiastowa rozbiórka „do wysokości muru zdrowego". Wymurowanie tego fragmentu od nowa miało zostać sfinansowane przez winowajcę, co było wyrazem wierności art. 659 $\mathrm{KN}^{35}$. Strony zastrzegły zarazem, że po zakończeniu prac wspólność muru będzie obowiązywać tylko do pierwotnej wysokości, ale już nie w stosunku

${ }^{33}$ Art. 653: „W miastach i wsiach każdy mur służący do oddzielenia budynków aż do dachu, albo pomiędzy podwórzem i ogrodami, a nawet między ogrodzeniem w polach, poczytywany jest za środkowy, jeżeli nie masz dowodów lub znaków na przeciwną stronę".

${ }^{34}$ Akt notarialny sporządzony przez notariusza Wojciecha Olearskiego 11 grudnia $1835 \mathrm{r}$. O wolności umów w Kodeksie Napoleona zob. K. Sójka-Zielińska, Kodeks Napoleona..., s. 114-118.

${ }^{35}$ Art. 659: „Jeżeli mur środkowy nie jest w stanie utrzymać podniesienia, żądający go podnieść powinien go przestawić swoim kosztem, i przybywająca grubość brana być powinna $\mathrm{z}$ jego strony”. 
do podwyższenia, co wyrażało rezygnację $\mathrm{z}$ rozwiązania zapisanego $\mathrm{w}$ art. $660 \mathrm{KN}^{36}$.

Nie mniej poważne uszkodzenia dotknęły również odcinek B-C, i w tym przypadku niezbędne było jego „wyburzenie i wymurowanie na nowo”, z pogrubieniem konstrukcji do dwóch stóp i sześciu cali ${ }^{37}$. Należy dodać, że w omawianym przypadku pojawiła się kwestia ,ś́cieku z dachów”, czyli uregulowanego w oddziale IV (działu II) zakazu kierowania spływu (opadu) wody deszczowej na grunt sąsiada. Ustalając termin realizacji inwestycji (24 czerwca 1836 r.), strony uzgodniły, że ,jakikolwiek okap na część Wermuthów" jest zabroniony (art. $681 \mathrm{KN})^{38}$.

Pełnomocnik Wermuthów (adwokat Jan Kanty Rzesiński) podnosił, że podczas prac budowlanych Gajdziński dopuścił się licznych nieprawidłowości i nadużyć (działań „bezprawnych i ponad osnowę aktu”), nie wykonując umowy („nie czyniąc zadość zobowiązaniu”). Po pierwsze, przy rozbieraniu fragmentu muru wyznaczonego linią D-E uszkodził tylną facjatę domu pod L. 100, w tym ganki i komórki. Nie stosował się też do planów robót na odcinku $\mathrm{A}-\mathrm{B}$, zaś w linii $\mathrm{B}-\mathrm{C}$, wszedł na 1 łokieć ze swoim murem na grunt Wermuthów". Łącznie pod budowę nowego muru zabrał cztery sążnie kwadratowe należące do Wermuthów, naruszając tym samym postanowienia aktu notarialnego. Wermuthowie żądali więc utrzymania $\mathrm{w}$ „spokojnym posiadaniu" muru wyznaczonego linią D-E, wokół którego nie prowadzono wtedy (,w przestrzeni 5 sążni i 2 stóp”) żadnych prac; domagali się też odbudowania przez Gajdzińskiego pozostałej części muru, w tej samej wysokości i grubości, jak też wymurowania ,zburzonych ganków i komórek"39.

Adwokat Stanisław Boguński, pełnomocnik Gajdzińskiego, odrzucił zarzuty przeciwników, w pierwszej kolejności wskazując na wyrok sądu po-

${ }^{36}$ Art. 660: „Sąsiad, który się nie przykładał do podniesienia, może jego środkowości nabyć, płacąc połowę kosztów na podniesienie, i połowę wartości gruntu, jeżeli był zajęty na dodatek grubości”. Z takiej możliwości nie skorzystał Wermuth.

${ }^{37}$ ANK, Archiwum Wolnego Miasta Krakowa, sygn. 29/200/1758, s. 2279-2281 („Odpowiedź Józefa i Katarzyny Gajdzińskich”). Strony zobowiązały się do „ustąpienia gruntu” po połowie, przy czym wspólność miała objąć całość przebudowanego fragmentu.

${ }^{38}$ Art. 681: „Każdy właściciel tak powinien zakładać dachy, aby deszczowe z nich wody spływały na jego ziemię, albo na drogę publiczną, a nigdy dawać nie może ścieku wód takich na grunt sąsiada swojego".

39 ANK, Archiwum Wolnego Miasta Krakowa, sygn. 29/200/1758, s. 2275-2277 („Uciążliwości ze strony Izaaka i Sary Wermuthów przeciwko Józefowi Gajdzińskiemu” z 4 czerwca 1837 r.). Oszacowaniem wyrządzonych strat mieli się zająć biegli. 
koju, który stwierdził, że Wermuthowie nie wykazali, aby doszło do naruszenia spokojnego posiadania; nie potrafili też określić, jak mur wyglądał wcześniej oraz jakie nastąpiły w nim zmiany; a także, czy ganki i komórki istotnie zostały wyburzone bez ich wiedzy i zgody. Reasumując, nie wykazali, aby Wermuthowie dopuścili się złamania warunków umowy, toteż sąd pokoju uznał ich żądanie za „niewyjaśnione i nieudowodnione”. Innym ważnym dowodem zadającym kłam twierdzeniom Wermuthów był także wydany na podstawie ustaleń biegłych reskrypt Wydziału Spraw Wewnętrznych, w którym stwierdzono, że Gajdzińscy przejęli na swoją rzecz jedynie kawałek muru o grubości 5-6 cali, „oddając w zamian pewną grubość”; wprowadzone zmiany były „z korzyścią dla obu stron”, nie mogły więc stać w sprzeczności z umową. Gajdziński dodawał, że z zasad budownictwa wynika, iż ,przesunięcie jednej cegły nie może być powodem burzenia całego muru". Poza tym Wermuthowie regularnie przychodzili na plac budowy, więc ,wszystko odbywało się za ich wiedzą"40.

W dalszej części pisma adwokat skoncentrował swoje wysiłki na przekonaniu sądu, że jego klient mógł przebudować, a więc także pogrubić mur nie tylko w sposób określony umową, ale także na podstawie elastycznych przepisów art. $1135 \mathrm{i} 1156 \mathrm{KN}^{41}$. Wynikało z tego niezaprzeczalnie, iż to właśnie żądanie Wermuthów dotyczące przywrócenia muru do poprzedniej postaci było przeciwne umowie i planowi robót ${ }^{42}$.

W omawianej sprawie pojawiły się też wątpliwości co do właściwości sądów pokoju, gdyż Gajdzińscy kwestionowali dopuszczalność rozpatrywania przez nie kwestii petytoryjnych, czyli związanych z realizacją prawa własności (w tym spory o ważność umów) ${ }^{43}$. Należy wyjaśnić, że zgodnie

${ }^{40}$ Ibidem, s. 2279-2281 („Odpowiedź Józefa i Katarzyny Gajdzińskich”); reskrypt Wydziału Spraw Wewnętrznych z 4 lipca 1836 r.

${ }^{41}$ Art. 1135: „Umowa obowiązuje nie tylko do tego, co w niej wyrażone, ale też jeszcze i do wszystkich następujących wypadków, które słuszność, zwyczaj albo prawo nadaje zobowiązaniu podług jego natury”. Art. 1156: „Potrzeba poszukiwać w umowach więcej tego, jaki był zamiar stron kontraktujących, aniżeli zatrzymywać się nad literalnym znaczeniem wyrazów".

${ }^{42}$ ANK, Archiwum Wolnego Miasta Krakowa, sygn. 29/200/1758, s. 2281 („Odpowiedź Józefa i Katarzyny Gajdzińskich”). Należy dodać, że prace budowlane miały być prowadzone według planu zatwierdzonego przez Oddział Budownictwa. Zob. M. Mataniak, Rada..., s. 184-196.

${ }^{43}$ ANK, Archiwum Wolnego Miasta Krakowa, sygn. 29/200/1758, s. 2279-2281 („Odpowiedź Józefa i Katarzyny Gajdzińskich”). Skierowanie sprawy badanej przez sąd pokoju przed Trybunał I Instancji Gajdziński uznał za „oczywiste pieniactwo”. 
z ustawą z 1825 r. w gestii sądów pokoju leżały sprawy, w których wartość przedmiotu sporu nie przekraczała 200 złp (orzekały wtedy jako organ I instancji); jeżeli wartość ta nie przekraczała $30 \mathrm{złp,} \mathrm{ich} \mathrm{orzeczenie} \mathrm{miało} \mathrm{walor}$ ostateczności. Dla sądów pokoju wyraźnie zastrzeżono też sprawy posesoryjne $^{44}$. Sędzia pokoju miał z urzędu badać swą właściwość w sprawie ${ }^{45}$. W Krakowie działały dwa sądy pokoju ${ }^{46}$.

Na tym etapie postępowania Sąd Apelacyjny uznał, że sprawa istotnie nie mogła być rozpoznawana przez sąd pokoju, gdyż nie został dochowany termin wnoszenia skarg posesoryjnych ${ }^{47}$. Dlatego uchylił wyrok i na podstawie art. 170 Kodeksu Procedury Cywilnej (dalej: KPC) ${ }^{48}$ odesłał sprawę Trybunałowi („do drogi prawa właściwej”) ${ }^{49}$. Ten ostatni uznał, że sięgnięcie do opinii biegłych, którzy mieli ustalić, czy w wykonaniu umowy notarialnej Gajdzińscy zastosowali się do zawartego w niej ,,planu robót” - było zasadne. Stanowisko takie podzielił Sąd Apelacyjny ${ }^{50}$.

${ }^{44}$ Ustawa Nadzwyczajnego Sejmu Prawodawczego z 17 czerwca 1825 r. „Prawo oznaczające postępowanie przed Sądami Pokoju w kraju Rzeczypospolitey Krakowskiey”, ogłoszona pismem Senatu Rządzącego nr 3647 DGS, Dziennik Praw Rzeczypospolitey Krakowskiey (dalej: Dz. Praw RK) z 1825 r., cz. 1: Postępowanie przed Sądami Pokoju. Zasady ogólne (art. 1-3).

${ }^{45}$ Ibidem. Tytuł I „O Audyencyach Sędziego Pokoju i o stawieniu się Stron” (art. 21, pkt 1-2). Dotyczyło to także badania zdolności procesowej stron.

${ }^{46}$ Oprócz tego po jednym w Chrzanowie, Krzeszowicach i Mogile; urząd sędziego pokoju był funkcją honorową; powoływało ich na 3-letnią kadencję Zgromadzenie Reprezentantów spośród kandydatów wyłonionych przez gminne zgromadzenia obiorcze; element fachowy w sądzie stanowił pisarz (pensja 2000 złp rocznie +500 złp na prowadzenie biura).

${ }^{47}$ Art. 31: „Skargi in possesorio takie tylko przyjętymi będą, które najdalej w rok po nastąpieniu naruszenia possesji wniesionymi zostaną przez osoby, które były przynajmniej od roku w posesji spokojnej i od łaski cudzej niezawisłej, bądź osobiście, bądź przez osoby do nich należące”. Zastosowanie powinien znaleźć także art. 33: „Skarga o posiadanie (possesorium) nie będzie nigdy razem wnoszoną ze skargą o prawo posiadania (petitorium)". Tytuł III „O Wyrokach zapadłych na wniesione skargi in Possesorio”.

${ }^{48}$ Art. 170: „Gdyby jednakowoż Sąd nie był właściwym co do materii, żądać będzie można odesłania w jakimbykolwiek bądź stanie proces się znajdował; a gdyby nie żądano odesłania, Sąd obowiązany będzie odesłać z urzędu tam, gdzie należy”. Tytuł IX „O excepcyach".

${ }^{49}$ ANK, Archiwum Wolnego Miasta Krakowa, sygn. 29/200/1758, k. 2271-2273 (wyrok Sądu Apelacyjnego z 22 czerwca 1837 r.). Sąd orzekł też „zniesienie kosztów”.

${ }^{50}$ Ibidem, sygn. 29/200/1761, s. 911-913 (wyrok Sądu Apelacyjnego z 28 sierpnia 1838 r.; wyrok Trybunału I Instancji z 18 maja 1838 r.). Na biegłych sąd wyznaczył ar- 
Na marginesie głównych rozważań warto dodać, że w przedmiocie aktu notarialnego Wermuthowie wskazywali nie tylko na art. 1135 i 1156, ale także art. 1273 i $1341 \mathrm{KN}$. Ten ostatni dotyczył wymogu zawierania umów, w których wartość przedmiotu przekraczała 150 franków, w formie aktu notarialnego, a przynajmniej $\mathrm{w}$ postaci dokumentu z podpisem prywatnym dla celów dowodowych (ad probationem). W przeciwnym razie uciekanie się do zeznań świadków było niedozwolone - co rodziło więc wątpliwości co do trafności orzeczenia Sądu Apelacyjnego ${ }^{51}$.

\section{Sprawa Raabów przeciwko Wysockiemu}

Wśród kazusów szczególnie bogatych w treści jurydyczne można wskazać proces między małżeństwem Raabów - Ignacym i Klarą z Rydlów, właścicielami kamienicy przy ulicy Stolarskiej 46 (obecnie Stolarska 13 - dawny klasztor dominikanek, tzw. większy), reprezentowanymi przez S. Boguńskiego, a Franciszkiem Wysockim, właścicielem domu przy ulicy Grodzkiej 30 (obecnie Grodzka 6), którego pełnomocnikiem był Feliks Słotwiń$\mathrm{ski}^{52}$. Geneza sprawy sięgała połowy lat 20 . XIX w., kiedy to Raabowie zainicjowali przebudowę widermachu. Ponieważ zakłócał on swobodny dostęp do światła, Franciszek Marczyński, poprzedni właściciel kamienicy pod L. 30, wytoczył przed sąd pokoju powództwo posesoryjne, domagając się przywrócenia „spokojnego posiadania” służebności widoku. Te działania kontynuowali następcy prawni Marczyńskiego - małżonkowie Gajdzińscy, a w końcu także Wysocki ${ }^{53}$.

Dopiął on swego 12 września 1831 r., kiedy sąd pokoju wydał wyrok utrzymujący go w spokojnym posiadaniu, nakazujący Raabom przywrócenie widoku trzem oknom na pierwszym i drugim piętrze jego kamienicy (poprzez odsunięcie oficyny na wymaganą odległość) oraz wzbraniający im

chitektów (Karol Kremer, Tomasz Majewski, Jan Bogumił Trenner), od których przysięgę odebrał zastępca sędziego Ekielski.

${ }^{51}$ Ibidem, s. 915-917 („Wywód uciążliwości ze strony Gajdzińskich”); s. 919 („Odpowiedź ze strony Wermutów przeciwko Gajdzińskim,”). Art. 1273 KN dotyczył odnawiania zobowiązań.

${ }^{52}$ Plan miasta Krakowa..., s. 12 (oraz sekcja 41 - plan z identyfikacją adresów).

${ }^{53}$ ANK, Archiwum Wolnego Miasta Krakowa, sygn. 29/200/1670, s. 1029-1030 („Odpowiedź Franciszka Wysockiego na Uciążliwości Ignacego i Klary Raabów Małżonków”); s. 1022-1023 („Pozew rekurrujących Raabów” - doręczony przez woźnego 12 czerwca 1833 r.). 
„wszelkiej budowy”. Orzeczenie zapadło na podstawie zeznań świadków i opinii biegłych ${ }^{54}$. Sprawa nie była jednak zakończona. Aby rozsądzić spór, sądy musiały odpowiedzieć na kluczowe pytanie: czy Wysocki skutecznie nabył służebność widoku i w związku z tym mógł się domagać odsunięcia oficyny? Przez wzgląd na art. 688-689 KN należało przyjąć, że prawo widoku - o czym była już mowa - jest służebnością ciągłą i widoczną, a więc może zostać nabyta przez zasiedzenie (per prescriptione longissimi temporis $)^{55}$.

Aby to udowodnić, Wysocki sięgnął po rozmaite środki dowodowe, w tym dokumenty urzędowe. Wśród nich trzeba wskazać chronologicznie najwcześniejszy dział sądowy z 1748 r. zawarty między Pączkowskimi a Karaszewskim - dawnymi właścicielami kamienic ${ }^{56}$. Dalej akt notarialny z 1818 r., na podstawie którego doszło do przeniesienia na rzecz Raabów własności kamienicy pod L. 46 ${ }^{57}$. Fakt „odwiecznej obecności” okien na drugim piętrze kamienicy Wysocki usiłował wykazać także przy pomocy protokołów posiedzeń (,ustaleń urzędowych”) dwóch komisji: posesoryjnej, którą wyznaczył Trybunał I Instancji ${ }^{58}$, oraz administracyjnej - wydelegowanej przez Senat Rządzący dla zbadania, czy przy restauracji kamienicy pod L. 30 przestrzegano prawa budowlanego ${ }^{59}$. Przywoływał też zeznania

${ }^{54}$ ANK, Archiwum Wolnego Miasta Krakowa, sygn. 29/200/1683, s. 991-992 (relacja sędziego sprawozdawcy z 12 kwietnia 1839 r.). Sprawozdawcą był Andrzej Kalinka.

${ }^{55}$ Zob. przyp. 21-22. J. J. Delsol (Zasady..., s. 478-479) twierdził, że w istocie ową służebność stanowi korzystanie $\mathrm{z}$ widoku jedynie poprzez otwór urządzony zbyt blisko gruntu sąsiedniego, a więc z naruszeniem parametrów technicznych, art. 676-680 KN.

${ }^{56}$ ANK, Archiwum Wolnego Miasta Krakowa, sygn. 29/200/1670, s. 1383-1384 („Odpowiedź Wysockiego na Uciążliwości Raabów”). Okres 1748-1825 (77 lat) stanowił czas wystarczający dla zasiedzenia; w aktach Karaszewski występuje też jako Karasiński.

${ }^{57}$ Ibidem, s. 1385-1386; akt notarialny z 18 grudnia 1818 r., sporządzony przez notariusza Wojciecha Olearskiego. Raabowie dokonali wówczas nabycia „w takim stanie, w jakim się kamienica znajdowała” - wszelako „okna były tam od 70 lat”.

${ }^{58}$ ANK, Archiwum Wolnego Miasta Krakowa, sygn. 29/200/2007, b.p. („Odpowiedź Wysockiego na Konkluzję Raabów”). Wyznaczona na wniosek Wojciecha Marczyńskiego komisja posesoryjna badała w dn. 26 sierpnia 1831 r. , odjęcie widoku” mieszkańcom L. 46 wywołane „murowaniem oficyny” i remontem dachu, a także „dezolacje” w nowym murze spowodowane ,zamakaniem muru przez ścieki wody” (przyczyną był brak rynny).

${ }^{59}$ Ibidem, sygn. 29/200/1670, s. 1385-1386 („Odpowiedź Wysockiego na Uciążliwości Raabów”). Decyzją z 27 października 1830 r. nr 5868 komisja stwierdziła zgodność „,planów przebudowy” z prawem budowlanym; ustaliła, że „mury tegoż widermachu mają w piętrze swoim odstępy na stronę Florera, a teraz Wysockiego, właścicieli kamienicy pod 
Jerzego Florera, od którego kupił kamienicę; ponadto relację małżonków Gajdzińskich, wezwanych przez Trybunał w charakterze ewiktorów ${ }^{60}$ oraz innych świadków dopuszczonych przez sąd pokoju ${ }^{61}$.

Swoje środki dowodowe przedstawili też Raabowie. Był to np. pochodzący z 1816 r. raport komisji wydelegowanej przez prezydenta Municypalności, która miała zbadać stan techniczny budynku pod L. 30 - w związku z jego sprzedażą Wojciechowi i Katarzynie Marczyńskim przez Antoniego i Konstancję Błońskich jeszcze w 1790 r. W raporcie stwierdzono, że w miejscu, w którym później znalazły się okna Wysockiego, przylegała oficyna podpierająca widermach. Ten zaś używało zgromadzenie Panien Dominikanek na potrzeby przyklasztornej kuchni ${ }^{62}$.

W jednym z wyroków Trybunał stanął na stanowisku, że dla wyjaśnienia sprawy niezbędne jest skorzystanie z wszelkich środków dowodowych, czyli dokumentów, „inkwizycji świadków” i „relacji znawców”. Dlatego przed „osądzeniem przedstanowczym” (kwestie wpadkowe) wydelegował sędziego Wojciecha Skarżyńskiego, który miał odebrać przysięgę od biegłych i przesłuchać świadków ${ }^{63}$. Wyrok Trybunału został uchylony przez Sąd Apelacyjny i Sąd III Instancji, które oddaliły żądania Raabów ${ }^{64}$. Warto dodać, że adwokat Raabów próbował przekonać sądy, że reskrypty Wydzia-

L. 30, których na stronę Raaba nie ma” (znaki nieśrodkowości). Zdaniem Słotwińskiego ustalenia komisji dowodziły, że „okna z dawien dawna tam istniały”.

${ }^{60}$ Ibidem, sygn. 29/200/2007, b.p. (wyrok Trybunału I Instancji z 24 lutego 1832 r.). Świadkowie zgodnie stwierdzili, że „okna od dawnego czasu egzystowały”, więc nastąpiło „,przedawnienie służebności”.

${ }^{61}$ Ibidem, sygn. 29/200/1670, s. 1030-1031 („Odpowiedź Franciszka Wysockiego na Uciążliwości Ignacego i Klary Raabów Małżonków”). Świadkami byli Franciszek Kałuziński i Franciszek Elsner.

${ }^{62}$ Ibidem, sygn. 29/200/2007, b.p. („Odpowiedź Raabów na Punkt Incydentalny Wysockiego”); ibidem, sygn. 29/200/1670, s. 1022-1028 („Pozew rekurrujących Raabów” z 12 czerwca 1833 r.). Oficyna stanowiła wówczas pawilon „klasztoru większego".

${ }^{63}$ Ibidem, sygn. 29/200/2007, b.p. (wyrok Trybunału I Instancji z 24 lutego 1832 r.). Świadkowie mieli też odpowiedzieć na pytanie, czy w chwili nabycia kamienicy przez Marczyńskich od Błońskich okna były już zamontowane.

${ }^{64}$ Ibidem, sygn. 29/200/1683, s. 993-994 (relacja sędziego sprawozdawcy z 12 kwietnia 1839 r.); wyrok Sądu Apelacyjnego z 1 maja 1833 r.; wyrok Sądu III Instancji z 13 maja $1834 \mathrm{r}$. 
łu Spraw Wewnętrznych jako akty administracyjne nie mogą być wykorzystywane $\mathrm{w}$ procesie cywilnym ${ }^{65}$.

W sprawie pojawił się także wątek zgłaszania służebności - przy okazji tzw. regulacji hipoteki ${ }^{66}$. Powołując się na decyzję Komisji Hipotecznej, Raabowie przekonywali, że zgłoszenia zaniedbał jeden z poprzednich właścicieli domu pod L. 3067. Ów zarzut pełnomocnik Wysockiego uznał za nietrafny, gdyż to Raabowie jako powołujący się na prawo domagania się od sąsiada zamurowania okien, powinni je byli zgłosić przy regulacji ${ }^{68}$. Przekonywał, że nawet gdyby właścicielom nieruchomości L. 46 przysługiwała służebność polegająca na możliwości zakazania sąsiadowi „wybicia okien”, co ograniczało jego prawo własności, to i tak do tego czasu utraciliby ją wskutek niewykonywania ${ }^{69}$. Dodawał, że Raabowie nie udowodnili nabycia tej służebności „w jakikolwiek bądź sposób prawny, przez dział umowny, testament lub przedawnienie" $"$.

Powyższy tok rozumowania Słotwińskiego stanowił próbę spojrzenia na służebności od strony „biernej”. Obciążenie gruntu służebnością może bowiem polegać na obowiązku powstrzymywania się od realizacji uprawnień

${ }^{65}$ Ibidem, sygn. 29/200/2007, b.p. („Odpowiedź Raabów na Punkt Incydentalny Wysockiego"). Rozstrzygnięcie sprawy było możliwe jedynie na podstawie przepisów ustaw cywilnych; reskrypty dotyczyły „pozwolenia na przebudowę”.

${ }^{66}$ Od 1822 r. właściciele nieruchomości, osoby twierdzące, że mają co do własności prawo lepsze bądź równe, a także osoby uprawnione z tytułu praw rzeczowych oraz zgłaszające pretensje do długów i obciążeń hipotecznych były wzywane przez Komitet Hipoteczny do składania dowodów, na których opierało się ich prawo. Zob. Dorota Malec, Z dziejów prawa hipotecznego Wolnego Miasta Krakowa, „Czasopismo Prawno-Historyczne” 2004, t. 56, z. 1, s. 88-89.

${ }^{67}$ ANK, Archiwum Wolnego Miasta Krakowa, sygn. 29/200/1749, s. 545-547 („Wywód Uciążliwości ze strony Raabów” z 23 marca 1833 r.); ibidem, sygn. 29/200/2007, b.p. (pozew Raabów doręczony przez woźnego); decyzja Komitetu Hipotecznego z 19 maja 1828 r. nr 343 stwierdzająca, że właściciel L. 30 „,nie zgłosił zastrzeżeń w terminie prekluzyjnym i półrocznym".

${ }^{68}$ Ibidem, sygn. 29/200/1670, s. 1385-1386 („Odpowiedź Wysockiego na Uciążliwości Raabów"). Dodawał, że jeżeli prawo wybicia okna we własnym murze traktować jako służebność, to fakt jego niezgłoszenia nie mógłby skutkować utratą tej służebności.

${ }^{69}$ Ibidem, sygn. 29/200/1670, s. 1383-1384 („Odpowiedź Wysockiego na Uciążliwości Raabów").

${ }^{70}$ Ibidem, sygn. 29/200/2007, b.p. (,Punkt Incydentalny ze strony p. Wysockiego przeciwko p. Raabom” z 2 lutego 1831 r.; „Odpowiedź Wysockiego na konkluzję Raabów”). Słotwiński wskazywał na istotę służebności, jako „ciężaru włożonego na dziedzictwo, dla użyteczności i pożyteczności drugiego dziedzictwa”. 
właścicielskich. Chcąc pomóc klientowi, Słotwiński uciekał się do różnej argumentacji. Także tej, że prawo wybicia okien wynika wprost z uprawnień właścicielskich - a nie, że jest rezultatem zasiedzenia służebności polegającej na zmuszeniu sąsiada do rezygnacji z jego uprawnień; zwracał uwagę na jedną z naczelnych zasad KN (art. 544) głoszącą, że każdemu właścicielowi przysługuje prawo używania rzeczy i rozporządzania nią (,dysponowania w sposób najrozciąglejszy"), w granicach obowiązującego prawa ${ }^{71}$. Będąc właścicielem kamienicy, Wysocki stał się dysponentem służebności jako „prawa rzeczowego przywiązanego do nieruchomości”72.

W sprawie Wysockiego pojawiło się też pytanie, czy mur między posiadłościami jest „środkowy”, czy też stanowi wyłączną własność Wysockiego. Odpowiedź na to pytanie była o tyle istotna, że jedynie właścicielowi muru „środkowego" wolno było wybijać „otwory dla światła” zamknięte nieruchomymi szybami, a także montować „okna okratowane i nie otwierające się", nawet bez zgody sąsiada. Przy tej okazji istotne było też zachowanie odpowiedniej odległości okna od nieruchomości sąsiedzkiej (art. 676-680 $\mathrm{KN}$ ). Pełnomocnik Raabów przekonywał, że początkowo jego klienci wcale nie domagali się stwierdzenia wspólności bądź wyłączności, lecz natychmiastowego zamurowania okien przez Wysockiego na podstawie art. 678 i $680 \mathrm{KN}$, czyli z powodu niedochowania wymogu odpowiedniej odległości okien od obserwowanej posiadłości Raabów ${ }^{73}$.

Paradoksalnie na te same przepisy powoływał się także Wysocki. Przypominał, że sąd pokoju nakazał Raabom odsunąć dopiero co wzniesioną oficynę „na odległość określoną w prawie i urządzeniach miejscowych”74. Raabowie twierdzili bowiem, że skoro mur jest środkowy, to przysługuje

${ }^{71}$ Ibidem, sygn. 29/200/1670, s. 1383-1384 („Odpowiedź Wysockiego na Uciążliwości Raabów”). W wykonywaniu prawa ,żaden właściciel tamowanym być nie może”. O prawie własności w kodyfikacjach XIX w. (KN, BGB, ABGB): Katarzyna Sójka-Zielińska, Wielkie kodyfikacje cywilne. Historia i współczesność, Warszawa 2009, s. 115-119, 209-211, 323-325; Andrzej Dziadzio, Powszechna historia prawa, Warszawa 2009, s. $327-328$.

${ }^{72}$ ANK, Archiwum Wolnego Miasta Krakowa, sygn. 29/200/1670, s. 1034-1035 („Odpowiedź Franciszka Wysockiego na Uciążliwości Ignacego i Klary Raabów Małżonków”).

${ }^{73}$ Ibidem, sygn. 29/200/2007, b.p. („Odpowiedź Raabów na Punkt Incydentalny Wysockiego"). Akcentował też konieczność odrębnego traktowania przez sądy kwestii posesoryjnych i petytoryjnych.

${ }^{74}$ Wyroki sądu pokoju okręgu II: z 1 i 10 sierpnia 1825 r. (zatwierdzony przez Sąd Apelacyjny wyrokami z 16 listopada 1825 - zaocznym, z 25 stycznia 1826 - ocznym); 
im prawo postawienia przy nim oficyny, i tym sposobem zamknięcia okien Wysockiego, tak że całkowicie znikną ${ }^{75}$. Dowodzili też, że sąd pokoju zarządzając „odsunięcie całej oficyny, jak gdyby była jaką rzeczą ruchomą, jak stolik lub stołek", orzekł ponad żądanie strony (ne ultra petita partium), gdyż poprzedni właściciel (Marczyński) domagał się jedynie zdjęcia rynny, po której woda deszczowa spływała na jego posiadłość. Niebagatelną rolę odgrywał aspekt finansowy, gdyż usunięcie oficyny groziło zawaleniem całego widermachu, którego wartość Raabowie oszacowali na poważną sumę $20000 \mathrm{złp}^{76}$.

Apelację Raabów Sąd Apelacyjny jednak odrzucił77. Uznał, że nie wykazali oni, aby kiedykolwiek doszło do ograniczenia właścicieli kamienicy L. $30 \mathrm{w}$ prawie wybicia okien - tym samym nigdy nie ustanowiono ,środkowości” muru. Oddalił więc żądanie Raabów zamurowania okien przez Wysockiego oraz wynagrodzenia szkód ${ }^{78}$.

Należy odnotować, że opinię w sprawie wydał też Wydział Prawa UJ ${ }^{79}$. Badając wyroki sądu pokoju (1831-32) i Sądu Apelacyjnego, profesorowie dostrzegli obrazę prawa materialnego (art. $1351 \mathrm{KN}^{80}$ ) i procesowego (art.

z 26 i 31 sierpnia 1831 r. (przedstanowczy, dotyczący inkwizycji ze świadków) oraz 1 i 12 września 1831 r. (stanowczy, dotyczący opinii biegłych).

${ }^{75}$ Zob. J. J. Delsol, Zasady..., s. 476-477.

${ }^{76}$ ANK, Archiwum Wolnego Miasta Krakowa, sygn. 29/200/1670, s. 1022-1028 („Pozew rekurrujących Raabów” z 12 czerwca 1833 r.). Pozew doręczył woźny Józef Długoszewski. O tym, że oficyna była „przytykiem do domu L.30” przekonywał protokół z 1816 r., kiedy ani Raabowie, ani Wysocki nie byli właścicielami kamienic.

77 Ibidem, sygn. 29/200/1748, s. 753-755 (wyrok Sądu Apelacyjnego z 27 lutego 1833 r.); s. 757-760 (,Wywód Uciążliwości ze strony P. Ignacego Raaba”); s. 761 („Wywód Wysockiego"). Podstawą wyroku były art. 678 i $680 \mathrm{KN}$.

${ }^{78}$ Ibidem, sygn. 29/200/1749, s. 537-544 (wyrok Sądu Apelacyjnego z 1 maja 1833 r.). Sąd Apelacyjny uchylił też wyrok Trybunału w sprawie ponownego przeprowadzenia czynności na miejscu, uznając czynności sądu pokoju za wystarczające.

${ }^{79}$ Archiwum Uniwersytetu Jagiellońskiego, sygn. WP I 59, s. 169-171 (opinia Wydziału Prawa UJ z 5 czerwca 1833 r.); ANK, Archiwum Wolnego Miasta Krakowa, sygn. 29/200/1670, s. 1021-1022 (odpis opinii). Opinię w sprawie wyroku Sądu Apelacyjnego z 27 lutego 1833 r. wydali Antoni Matakiewicz, Józef Jankowski, Piotr Bartynowski, Ferdynand Kojsiewicz, Wincenty Szpor i Jan K. Rzesiński. Prośba wpłynęła na dziennik podawczy UJ 4 kwietnia $1833 \mathrm{r}$.

${ }^{80}$ Art. 1351: „Powaga rzeczy osądzonej względem tego tylko ma miejsce, co czyniło przedmiot wyroku. Potrzeba, aby rzecz żądana taż sama była, żeby żądanie zasadzone było na tejże samej przyczynie; żeby żądanie było między tymiż samymi stronami, i zanoszone przez nie, i przeciw nim, w tym samym ich przymiocie". 
$\left.256 \mathrm{KPC}^{81}\right)$. Opinia skutkowała kasacją do Sądu III Instancji, który podtrzymał tezę o bezzasadności rekursu Raabów, nakazując im odsunięcie oficyny, i tym samym przywrócenie widoku oknom domu Wysockiego ${ }^{82}$. W jeszcze jednym wyroku sąd uwypuklił tezę, że znaczenie rozstrzygające dla sprawy miały dokumenty urzędowe (dział sądowy z 1748 r. itd.) ${ }^{83}$. Poważne zarzuty pod adresem fakultetu prawnego sformułował jednak, sam będący profesorem prawa, F. Słotwiński. Twierdził, że pytania do Wydziału w ogóle nie obejmowały zarzutu bezprawnego przesłuchania biegłych i świadków (naruszenie art. $60 \mathrm{KPC}$ ), zaś apelacja w przedmiotach już prawomocnie osądzonych (res iudicata) była nieprzyjmowalna. Kontrświadków (świadków „W odwodzie”) należało wzywać na rozprawę główną, a nie jedynie poprzez notę, zaś zarzut obrazy art. $1351 \mathrm{KN}$ i $41 \mathrm{KPC}$ był nietrafny ${ }^{84}$.

Omawiana sprawa stanowi okazję dla prezentacji metod prowadzenia postępowań egzekucyjnych. Egzekucja prawomocnych wyroków należała w Wolnym Mieście Krakowie do komorników (,urzędników wykonawczych sprawiedliwości cywilnej”), którzy działali na podstawie KPC i innych regulacji ${ }^{85}$. Raabowie odwołali się od decyzji prezesa Trybunału, a także zatwierdzającej ją uchwały Sądu Apelacyjnego w przedmiocie egzekucji

${ }^{81}$ Art. 256: „Odwody same prawo dozwala: dowody powoda i odwody zaczną się i skończą w przeciągu czasu ustanowionym artykułami następującymi”. Tytuł XII „O Inkwizycyach”. Przepis gwarantował Raabom „odwód samym nawet prawem”.

${ }^{82}$ ANK, Archiwum Wolnego Miasta Krakowa, sygn. 29/200/1670, s. 1017-1020 (wyrok Sądu III Instancji z 16 stycznia 1834 r.). Sąd uznał, że ,przedstawione w rekursie uciążliwości nie zwątliły prawnych zasad zarekurrowanych wyroków”.

${ }^{83}$ Ibidem, s. 1365-1368, 1371 (wyrok Sądu III Instancji z 13 marca 1834 r.); s. 13731378 („Wywód Uciążliwości ze strony PP. Raabów przeciwko Wysockiemu, Gajdzińskiemu i sukcesorom Florera” z 11 stycznia 1834 r.); s. 1383-1386 („Odpowiedź Wysockiego na Uciążliwości Raabów").

${ }^{84}$ Ibidem, s. 1035-1036 („Odpowiedź Franciszka Wysockiego na Uciążliwości Ignacego i Klary Raabów Małżonków”). Słotwiński przekonywał ponadto, że w swej działalności sądy pokoju nie mogą stosować przepisów dla trybunałów.

${ }^{85}$ Były to: dekret z 14 października 1811 r. ,„powierzający funkcje burgrabiów woźnym i komornikom i ustalający związane z ich działalnością przepisy organizacyjne oraz należne opłaty”, Dziennik Praw Księstwa Warszawskiego, t. 3, nr 35, s. 407-413; Ustawa Nadzwyczajnego Sejmu Prawodawczego z 17 czerwca 1823 r. „O egzekucji sądowej”, ogłoszona pismem Senatu Rządzącego z 6 sierpnia 1823 r. nr 2116 DGS, Dz. Praw RK z 1823 r. (art. 1, 13); rozporządzenia Senatu Rządzącego: z 5 maja 1826 r. nr 1755 DGS „Postępowanie przy licytacjach, inwentacji itp.”, Dz. Praw RK z 1826 r.; z 9 września 1845 r. nr 4515 DGS „Instrukcja dla Komorników Sądowych”, Dziennik Praw Wolnego Miasta Krakowa (dalej: Dz. Praw WMK) z 1845 r. Zob. M. Mataniak, Urzędnicy.., s. 71-73, 87-92. 
prawomocnego wyroku nakazującego odsunięcie oficyny ${ }^{86}$. Sąd III Instancji stwierdził jednak, że wszystkie „rozstrzygające wątpliwość egzekucyjną orzeczenia dostosowały się do osnowy wyroku", uznał więc skargę Raabów za „nieprzyjmowalną do instrukcji w drodze kassacji”87.

Czynności egzekucyjne zlecono Wojciechowi Skórczyńskiemu, który doręczył Raabom wezwanie do złożenia w Kasie Sądowej zasądzonych kosztów - w ciągu 24 godzin. Ponieważ nie uczynili oni zadość wezwaniu, Skórczyński udał się do ich mieszkania, przybierając za świadków kilku sąsiadów. Jako że Raabowa oświadczyła, iż „kosztów nie zapłaci i egzekucji nie dozwoli”, komornik spisał „,protokół niesforności”, który przesłał prokuratorowi przy Trybunale ${ }^{88}$, z wnioskiem o „przydanie pomocy wojskowej”89. W trakcie kolejnej próby egzekucji Raabowie zgodzili się przywrócić widok „jedynie w jakowej części”. Prawidłową odległość między kamienicami odmierzyli biegli-architekci. Ich analizy techniczne pozwoliły też ustalić, że Raabowie powinni usunąć dwie belki osadzone w murach poprzecznych tuż obok okien Wysockiego, do czego, podobnie jak do rozbiórki, zobowiązali się w terminie ośmiu dni. W przeciwnym razie rozbiórkę miał wykonać Urząd Komorniczy - na ich koszt ${ }^{90}$.

W obliczu wątpliwości co do odsunięcia oficyny, a także stopnia wyburzeń, sąd wyznaczył kolejną „komisję na gruncie”, od której ustaleń Raabowie wnieśli do Sądu III Instancji ,instrukcję w drodze kasacji”. Sędzia sprawozdawca pytał sąd, czy możliwa jest egzekucja wyroków bez złożenia dowodu stanowczego. W jego ocenie konieczne było też ustalenie, jak daw-

${ }^{86}$ ANK, Archiwum Wolnego Miasta Krakowa, sygn. 29/200/1670, s. 1017-1020 (wyrok Sądu III Instancji z 16 stycznia 1834 r.); decyzja prezesa Trybunału I Instancji z 18 lutego 1834 r.; uchwała Sądu Apelacyjnego z 25-26 kwietnia 1834 r.

${ }^{87}$ Ibidem, sygn. 29/200/1672, s. 483-485 (wyrok Sądu III Instancji z 12 grudnia 1834 r.); s. 493-500 (skarga kasacyjna Raabów z 27 maja 1834 r.). Nie uchybiono też „formalnościom prawem zakreślonym".

${ }^{88}$ Prokuratorzy działali w oparciu o rozporządzenie Senatu Rządzącego z 14 czerwca 1826 r. nr 1137 DGS „Instrukcja dla Prokuratora Rządowego przy Sądach i Sądownictwie w ogólności”, ANK, Archiwum Wolnego Miasta Krakowa, sygn. 29/200/219, k. 11491154. Zob. M. Mataniak, Urzędnicy.., s. 92-95.

${ }^{89}$ ANK, Archiwum Wolnego Miasta Krakowa, sygn. 29/200/1672, s. 488-489 (relacja sędziego sprawozdawcy); s. 493-500 (skarga kasacyjna Raabów do Sądu III Instancji z 27 maja 1834 r.).

90 Ibidem, sygn. 29/200/1672, k. 487-488 (relacja sędziego sprawozdawcy). Byli to architekci Jakub Czerniński i Franciszek Pierret, którym towarzyszył wójt gminy I (Michałowski). 
niej wyglądały okna w kamienicy Wysockiego oraz na jaką odległość należy odsunąć oficynę. Czy dopuszczalne było wysłanie komornika, jeżeli nie upewniono się, że nie dojdzie do uszkodzenia muru i belek opartych o mur Wysockiego? ${ }^{91}$. Sprawozdawca stwierdził, że komornik miał prawo wyegzekwować wyroki posesoryjne i petytoryjne, ponieważ były one prawomocne. I chociaż Trybunał wstrzymał egzekucję i zarządził ponowne przesłuchanie biegłych oraz świadków, to decyzję tę uchylił Sąd III Instancji ${ }^{92}$. W związku z tym próbę wyegzekwowania wyroków podjął komornik Teodor Jaworski, któremu zrezygnowany Raab oświadczył, że „wolno mu robić, co mu się podoba". Doszło wówczas do odsunięcia oficyny od okien Wysockiego na wymaganą odległość 19 decymetrów (6 stóp); przywrócono też widok trzem oknom na pierwszym i drugim piętrze jego domu. Samowolne wykonanie przez Raabów drewnianego przepierzenia w miejscu częściowo rozebranej oficyny skutkowało decyzją Wydziału Spraw Wewnętrznych, który nakazał przywrócenie stanu zgodnego z prawem cywilnym i budowlanym ${ }^{93}$.

Spór toczył się do 1839 r., przedstawiany pod rozpoznanie Sądu III Instancji aż sześć razy (!). Pomimo licznych wyroków Raabowie uparcie domagali się przywrócenia przez Wysockiego muru w dawnej postaci itd. Sąd Apelacyjny stwierdził, że spór wynikły z aktu komorniczego powstał w czasie, gdy poprzednia egzekucja jeszcze trwała, więc powinien być traktowany jako nowy spór (nie znajdowała więc zastosowania zasada powagi rzeczy osądzonej, art. $1351 \mathrm{KN}$ ). Sąd zezwolił też na jeszcze jedno „naoczne obejrzenie" muru przez biegłych, którzy mieli stwierdzić, czy komornik

${ }^{91}$ Ibidem, s. 487-491 (relacja sędziego sprawozdawcy); s. 493-500 (skarga kasacyjna Raabów do Sądu III Instancji z 27 maja 1834 r.). Sąd III Instancji skasował wyroki Trybunału z 27 czerwca 1834 r. i Sądu Apelacyjnego z 7 stycznia 1835 r., ,przyjęte do instrukcji” wskutek zaskarżenia przez Wysockiego. Raabowie wnieśli też odwołanie co do kosztów sądowych.

${ }^{92}$ Ibidem, sygn. 29/200/1683, s. 994-995 (relacja sędziego sprawozdawcy z 12 kwietnia 1839 r.); wyrok Trybunału z 27 czerwca 1834 r.; wyrok Sądu III Instancji z 28 lipca $1835 \mathrm{r}$.

${ }^{93}$ Ibidem, s. 996-997 (relacja sędziego sprawozdawcy z 12 kwietnia 1839 r.); rozporządzenie Wydziału Spraw Wewnętrznych z 11 lipca 1837 r. nr 5137; uchwała Senatu Rządzącego z 13 stycznia 1838 r. nr 6973 DGS - zatwierdzenie decyzji Wydziału. Raabowie mieli wyprowadzić mur odgradzający oficynę od strony sąsiada; wstawić „drzwi wchodowe” nad rynną między oficynami, z pozostawieniem widoku oknom Wysockiego; chcąc budować kolejne piętro, musieli podwyższyć ścianę do określonej wysokości; przykazano im dbałość o rynny. Wysocki w „wychodzących nad rynnę” oknach na I i II p. miał wstawić żelazną kratę i drucianą siatkę dla zabezpieczenia Raabów od wyrzucania nieczystości. 
zastosował się do treści wyroków („,ducha wyroków”) 94 . Że tak było, stwierdził Sąd III Instancji, który ocenił, że wyburzenie kolejnego muru samowolnie wystawionego przez Raabów również było prawidłowe. Zatwierdził też orzeczenie Trybunału, które ostatecznie oddalało ich żądanie wystawienia przez Wysockiego muru przezeń wyburzonego ${ }^{95}$.

\section{Sprawa Zwierzynowej przeciwko Rozenfeldowi}

Służebności widoku dotyczył także kazus sukcesorów Józefa Zwierzyny, w których imieniu występował, jako kurator spadku, Antoni Matakiewicz, oraz Marianny Anny Zwierzynowej, wdowy po Józefie, zamieszkałej przy ulicy Grodzkiej pod L. 26 (obecnie Grodzka 2), przeciwko Samuelowi Rozenfeldowi, zamieszkałemu tamże pod L. 24/25 (obecnie Rynek Główny $13)^{96}$, którego reprezentował S. Boguński. Ten ostatni domagał się zamurowania okna w kamienicy pod L. 26 jako wybitego w cudzym murze i skierowanego na podwórze L. 24/25. W sprawie tej miała miejsce „rewizja naoczna okna" i ,inkwizycja w miejscu spornym”. Po zapoznaniu się ze zdaniem prokuratora Sąd Apelacyjny podtrzymał rozstrzygnięcie Trybunału i nakazał Zwierzynowej zamurowanie okna w murze „nieśrodkowym”97.

Spadkobiercy Zwierzyny przekonywali, że niekorzystny wyrok jest rezultatem błędnego przyjęcia, iż mur stanowi wyłączną własność Rozenfelda. Zdaniem sądu, wybite okno uniemożliwiało mu rozbudowę domu, stanowiło więc istotną niedogodność. Wezwani „w dowodzie” świadkowie

${ }^{94}$ Ibidem, sygn. 29/200/1761, s. 345-347 (wyrok Sądu Apelacyjnego z 26 lipca 1838 r.); ibidem, sygn. 29/200/2026, b.p. (wyrok Trybunału I Instancji z 4 maja 1838 r.). Na podstawie art. 295 i 302 KPC sąd wydelegował sędziego Wojciecha Dymidowicza i architektów (August Plasqude, Karol Kremer, Teofil Żebrawski). Po zapoznaniu się z opinią miał „postanowić, co z prawa wypadnie".

${ }^{95}$ Ibidem, sygn. 29/20/1683, s. 955-959 (wyrok Sądu III Instancji z 2 i 7 maja 1839 r.). Koszty zasądzono Wysockiemu. Zob. pisma w sprawie: s. 963-971 („Wywód Rekursu i Uciążliwości Franciszka Wysockiego przeciw Ignacemu i Klarze Raabom, małżonkom”); s. 975-980 („Odpowiedź na Rekurs ze strony Ignacego i Klary Raabów przeciwko Franciszkowi Wysockiemu”); s. 983-985 („Replika Wysockiego przeciw Raabom”); s. 987-989 („Duplika ze strony Raabów przeciwko Wysockiemu”); s. 996-997 (relacja sędziego sprawozdawcy z 12 kwietnia 1839 r.).

${ }^{96}$ Plan miasta Krakowa..., s. 11-12 (oraz sekcja 41 - plan z identyfikacją adresów).

${ }^{97}$ ANK, Archiwum Wolnego Miasta Krakowa, sygn. 29/200/1742, s. 785-788 (wyrok Sądu Apelacyjnego z 22 września 1835 r.); wyrok Trybunału I Instancji z 28 czerwca 1833 r. Parametry okna: wysokość 2 1/2, szerokość 2 1/4 łokcia, „przez całą grubość muru”. $\mathrm{Z}$ roszczeniem o wynagrodzenie Sąd odesłał strony „do osobnej drogi”. 
(w liczbie 5) zeznali, że przed kupnem kamienicy przez J. Zwierzynę nie było okna, lecz jedynie otwór z kratą żelazną „na krzyż”. Zapewniał on dopływ światła do kuchni, którą kilkanaście lat wcześniej Zwierzyna przerobił na pokój mieszkalny. Jak ustalił sąd, za zgodą administratora domu (Kasper Kozłowski) Zwierzyna wybił okno z zastrzeżeniem, że zamuruje je „W razie potrzeby”. Świadkowie wezwani „w odwodzie” nie potwierdzili, że okno przed nabyciem kamienicy było tych samych wymiarów. Jeszcze w 1832 r. Trybunał przysądził własność muru Rozenfeldowi, stwierdzając, że Zwierzyna może się bez tego okna obejść, gdyż ma w pobliżu inne, „Z prawej strony od wyjścia z sieni”. Powyższa argumentacja spotkała się z protestem spadkobierców Zwierzyny. Dotyczył on w pierwszej kolejności „nieśrodkowości” muru, który stanowił wprawdzie wyłączną własność, ale nie Rozenfelda, lecz Zwierzyny. Dowodziły tego przede wszystkim „mury fundamentowe" kamienicy L. 26, do których kiedyś były przytknięte schody i sklepienie; znajdowała się przy nim także piwnica, z której korzystał Zwierzyna (od strony Rozenfelda takiej nie było); innymi znakami nieśrodkowości (w każdym razie okolicznościami wykluczającymi wyłączną własność Rozenfelda) były belki wpuszczone w mur (,,przez całą grubość”) powyżej poziomu okna ,aż do pokojów Rozenfelda”; a także fakt opuszczenia przez Rozenfelda o jeden łokieć rynny znajdującej się na murze od strony Zwierzyny; własnością Zwierzyny był zresztą także mur oficyny, gdyż znajdowały się w nim belki „wychodzące na całą grubość” od strony jego domu. Jeszcze kilkanaście lat wcześniej miejsce, w którym stał domu Rozenfelda, było puste, podczas gdy kamienica Zwierzyny „egzystowała”, zaś po przybudowaniu się przez Rozenfelda nie doszło do nabycia przezeń środkowości muru od Zwierzyny (art. $661 \mathrm{KN}$ ). Odnośnie do niedogodności spowodowanej przez Zwierzynę, jego adwokat zwrócił uwagę, że „sprawiedliwość powinna być oceniana według prawa, a nie dogodności”. Wcale takie oczywiste nie było też istnienie żelaznej kraty. Znaleźli się świadkowie którzy pamiętali, że w kuchni znajdowało się „okno opatrzone szkłem, w jednej kwaterce”, otwierające się do środka ,prawie zawsze, jak się w niej paliło” (relacja 70-letniej Katarzyny Bednarskiej, byłej właścicielki L. 26; podobna, będącej w zbliżonym wieku, Teresy Kudasiewiczowej). 42-letni Franciszek Żrelski, który jeszcze jako nastoletni chłopak „bywał w tym domu”, również potwierdził fakt istnienia kuchennego „otworu dla światła”. Powyższe okoliczności stanowiły dowód, że Zwierzyna wcale nie potrzebował zgody zarządcy budynku na wybicie okna, ani też nie mógł się zobowiązać do jego 
zamurowania, gdyż okno istniało od ponad 30 lat, więc nawet gdyby przyjąć, że mur był własnością Rozenfelda i nie zawarto umowy, to i tak Zwierzyna zasiedziałby służebność widoku wskutek upływu czasu określonego w art. 690 i $2262 \mathrm{KN}$ (jego prawo było „,ugruntowane od niepamiętnych czasów”). Wzajemnie nie wykluczały się też zeznania świadków, którzy $\mathrm{w}$ istocie potwierdzili istnienie służebności. Z tą różnicą, że jedni twierdzili, iż był otwór z kratą, drudzy - że okno ze szkłem. Nieprawdą było, aby w ,zasadach wyroku” Trybunału (czyli niejako pośrednio) przyznana została własność dla Rozenfelda; wręcz przeciwnie - została zaprzeczona, przedmiotem sporu było co innego, zaś „,powody wyrokowania” (uzasadnienie) nie były samym wyrokiem i nie miały waloru prawomocności; obowiązywał też zakaz wyrokowania ponad żądanie. Zarzut niezgłoszenia tytułu do własności muru, a także służebności - przy licytacji sądowej, pełnomocnik Zwierzyny uznał za błędny, gdyż był on właścicielem całego domu, w tym „murów go składających”, nie musiał więc zgłaszać „własności częściowych"; ponieważ prawo widoku jest służebnością widoczną, nie było konieczności jej zgłoszenia do hipoteki (,takowe mogą być nabyte nawet przez zasiedzenie"); wręcz zdumiewająca i „sprzeciwiająca się wszelkiemu pojęciu prawa” była argumentacja, że Zwierzyna „ma drugie okno” (czy do pomyślenia byłoby pozbawianie kogoś własności tylko dlatego, że ma drugi, identyczny przedmiot?). Jeżeli Rozenfeld nadal utrzymywałby, że mur jest jego wyłączną własnością, to zdaniem adwokata Zwierzyny konieczne było powołanie biegłych ${ }^{98}$. Omawiany kazus może być także kanwą do rozważań nad kwestią, czy na potrzeby zasiedzenia służebności dopuszczalne jest sumowanie okresów, w których istniał najpierw „otwór z kratą”, a dopiero potem - tradycyjne okna. Na gruncie art. $676 \mathrm{KN}$ można przyjąć interpretację, że „okno okratowane i nie otwierające się” jest swego rodzaju odpowiednikiem „otworu dla światła”. W związku z tym, w ujęciu funkcjonalnym, należałoby przyjąć, że służebność światła jest czymś odrębnym od służebności widoku ${ }^{99}$.

Dla S. Boguńskiego, pełnomocnika Rozenfelda, kluczowa dla sprawy była odpowiedź na pytanie, czyją własność stanowi mur; a także, czy Zwie-

${ }^{98}$ Ibidem, s. 789-792 („Uciążliwości Sukcesorów Józefa Zwierzyny przeciwko Starozakonnemu Samuelowi Rozenfeld”); wyrok Trybunału I Instancji z 7 lipca 1832 r.

${ }^{99}$ Zob. J. J. Dels ol, Zasady..., s. 489-490. Jednakże przy zasiedzeniu istotniejsza jest uciążliwość, której właściciel obciążonej nieruchomości się nie sprzeciwia, której pobłaża, pozwalając spoglądać na swoje dziedzictwo (posesję). 
rzyna nabył służebność przez dokument bądź zasiedzenie. Sama analiza tych pytań pozwoliła mu zresztą na rezygnację ze ,szczegółowego rozbioru słów wyroku”. Na rzecz wyłącznej własności Rozenfelda przemawiał szereg faktów: treść wykazu hipotecznego kamienicy L. 24/25, decyzja Komitetu Hipotecznego, akt zajęcia nieruchomości na sprzedaż licytacyjną, obejrzenie naoczne biegłych, relacja świadków, konkluzja wyroku Trybunału (w której znalazł się nawet wniosek Zwierzyny o przyznanie wyłącznej własności Rozenfeldowi), na koniec wreszcie - przepisy KN. Nota opozycyjna Zwierzyny została oddalona, od wyroku zaocznego nie wniósł on apelacji, ale konkluzje wyroku musiały go przekonać, że właśnie z racji tego, że nie jest właścicielem muru, nie może dowolnie, czyli bez zgody sąsiada, „czynić otworów”. Obowiązywały go też: art. $662 \mathrm{KN}$ (zakaz wydrążania); art. $675 \mathrm{KN}$ (zakaz instalacji nawet „okna w szkła oprawnego”), a także art. 677, 678 i dalsze (zasady „szanowania własności”). Zakazane były więc także „okna przez mur obcy”, „otwieranie widoku na dziedzictwo, nieoddzielonego żadnym ustępem" (okno zbyt bliskie), jak również wszelkie działania „tamujące rozbudowę" przez właściciela. Boguński dowodził, że sukcesorowie Zwierzyny nie udowodnili nabycia służebności przy pomocy dokumentów (umowa) bądź w drodze ,przedawnienia” (art. 690 KN). Rozenfeld przedkładał „dowody prekluzji”, że gdyby nawet Zwierzyna miał kiedyś służebność, to już ją utracił, choćby poprzez fakt jej niezgłoszenia przy licytacji kamienicy, a później - regulacji hipotek. Wyłączną własność Rozenfelda potwierdził sędzia delegowany na grunt, przy udziale którego sporządzony został odpowiedni plan; ,znakami nieśrodkowości” były zaś ,,znaki framug na stronie Rozenfelda", które stanowiły realizację przesłanki z art. 654 KN. Domaganie się przez Zwierzynę nowej inkwizycji było bezzasadne, gdyż fakty, które tą drogą miano by udowodnić, były „niestosowne”; spór dotyczył murów, a nie własności domów; sędzia delegowany ustalił „znaki nieśrodkowości”, obecność biegłych była więc zbędna, zwłaszcza że ,sędzia niekoniecznie iść powinien za zdaniem biegłego"; świadkowie zeznali, że nie było okna, wybicie było warunkowe i tymczasowe, dlatego Boguński wnosił o uchylenie apelacji i zasądzenie kosztów jego klientowi ${ }^{100}$.

${ }^{100}$ ANK, Archiwum Wolnego Miasta Krakowa, sygn. 29/200/1742, s. 795-798 („Odpowiedź S. Rozenfelda"). Jak powiedziano wyżej, Sąd Apelacyjny przychylił się do argumentacji Boguńskiego. 


\section{Sprawa Wielopolskiego przeciwko Siemońskiemu}

Problematykę „,muru środkowego” można też dostrzec w sprawie hr. Andrzeja Wielopolskiego, właściciela pałacu przy ulicy Poselskiej pod L. 195 (obecnie ul. Poselska 12, czyli część gmachów Magistratu), przeciwko Anastazemu Siemońskiemu zamieszkałemu pod L. 194 (obecnie ul. Poselska $10)^{101}$. Geneza sprawy sięgała początku lat 20., kiedy Siemoński wyprowadził mury znacznej wysokości, chcąc „zabudować widermachy”. W latach 1822-1825 Wydział Spraw Wewnętrznych, na żądanie Wielopolskiego, wydał kilka rezolucji nakazujących wyburzenie muru ${ }^{102}$. Korzystając z pomocy adwokata, Wincentego Szpora, a także posiłkując się dokumentami oraz opiniami biegłych i relacjami świadków, Wielopolski domagał się przyznania mu wyłącznego prawa własności muru, a także wyburzenia przez Siemońskiego fragmentów grożących katastrofą budowlaną. Wskazywał przy tym na art. $659 \mathrm{KN}$ o konieczności ponoszenia kosztów przez właściciela muru nieśrodkowego, który doprowadził do nadmiernego obciążenia konstrukcji (Siemoński czynił to „na cudzym jak też wspólnym”); oraz art. $678 \mathrm{KN}$, ponieważ zbyt bliskie ,wyprowadzenie się z widermachami” przez Siemońskiego obok muru Wielopolskiego pozbawiło jego nieruchomość dostępu do światła. Z opinii biegłych wynikało, że mur „wzdłuż sieni przechodniej, aż do podworca”, jak też ,parkan między podworcami” były własnością Wielopolskiego; mur międzyparkanowy ,ppomiędzy podworcem oficyn” był wspólny - wobec „obustronnego okapu i framug”; główny mur między kamienicami („,między podworcami”) mógł stać się środkowym jedynie przez zasiedzenie $^{103}$. W ocenie Wielopolskiego czynienie przez biegłych uwag dotyczących kwestii petytoryjnych było niedozwolone - w swych badaniach mieli jedynie sprawdzać „kierunek i strukturę framug”, ewentualnie także inne ,znaki nieśrodkowości”"104.

${ }^{101}$ Plan miasta Krakowa..., s. 14 (oraz sekcja 49 - plan z identyfikacją adresów).

${ }^{102}$ ANK, Archiwum Wolnego Miasta Krakowa, sygn. 29/200/1997, s. 1009-1010 („Konkluzja ze strony Jaśnie Wielmożnego Hr. Wielopolskiego przeciw JW. Siemońskiemu”).

${ }^{103}$ Ibidem, s. 1011-1014 („Konkluzja ze strony Jaśnie Wielmożnego Hr. Wielopolskiego przeciw JW. Siemońskiemu”); ibidem, sygn. 29/200/1666, s. 341-348 („Wywód Rekursu ze strony Anastazego Siemońskiego przeciwko Wielopolskiemu”).

${ }^{104}$ Ibidem, sygn. 29/200/1997, s. 1011-1014 (,Konkluzja ze strony Jaśnie Wielmożnego Hr. Wielopolskiego przeciw JW. Siemońskiemu”). Wielopolski zarzucał sąsiadowi, że „osiadł czynem gwałtownym z oficyną”, zatarł jego „znaki własności”, a także spowodował „groźbę upadku budowli”. 
W omawianej sprawie sądy skoncentrowały się na interpretacji art. 653-654 KN. Na podstawie art. 254 KPC i na wniosek Siemońskiego, który domagał się przysądzenia wspólności muru, Trybunał nakazał przesłuchać świadków, spośród których każdy miał złożyć przysięgę na ustaloną przez sąd rotę: „Czy bywając w domu lub na podworcu L. 194 widział okap i framugi od strony dziedzińca L. 194 w murze tworzącym uliczkę znajdującą się między oficyną L. 195 a 194?”. A także: „Kiedy widział najwcześniej okap i framugi?" 105 . Interesującą i obszerną argumentację przedstawił w sprawie kolejny z pełnomocników Siemońskiego - Adam Krzyżanowski ${ }^{106}$. Żadna ze stron nie wykazała wyłącznej własności spornego fragmentu muru, a ponieważ nie udało się to również biegłym, Trybunał uznał go za wspólny, nakazując Siemońskiemu przestrzeganie odpowiednich przepisów $\mathrm{KN}^{107}$.

Badający sprawę Wydział Prawa UJ trafnie zwrócił uwagę na ewidentnie błędną interpretację przez sądy dość oczywistego zdawałoby się przepisu art. $654 \mathrm{KN}$. Wskazano w nim jedną z przesłanek (domniemań) pozwalających na uznanie muru za własność tylko jednego z sąsiadów. Mianowicie, jeżeli tylko od strony jego posiadłości mur „okazywał pochyłość”, znajdowały się w nim gzymsy, „wystające ustępy” bądź „wydrążenia (z kamieni) przy murowaniu porobione". Tymczasem w murze parkanowym, jak stwierdzał fakultet prawny, ,poczynając od tylnej facjaty aż do narożnika oficyny Wielmożnego Siemońskiego domu pod L. 194, są okapy i framugi z obu stron". Biorąc pod uwagę stan faktyczny, a contrario należało więc przyjąć, że mur jest wspólny ${ }^{108}$. W ten sam sposób na ów problem spojrzał Sąd III Instancji, uznając za konieczne ponowne obejrzenie

${ }^{105}$ Ibidem, sygn. 29/200/1666, s. 341-344 („Wywód Rekursu ze strony Anastazego Siemońskiego przeciwko Wielopolskiemu"). Świadków miał przesłuchać sędzia Onufry Męciński w ciągu miesiąca pod rygorem „uznania przeciwnych twierdzeń Wielopolskiego”.

${ }^{106}$ Ibidem, sygn. 29/200/1997, s. 1017-1018 („Obrona ze strony Siemońskiego przeciwko Wielopolskiemu”); ibidem, sygn. 29/200/1666, s. 341-348 („Wywód Rekursu ze strony Anastazego Siemońskiego przeciwko Wielopolskiemu”).

107 Ibidem, sygn. 29/200/1997, s. 997-998, 1000-1005 (wyrok Trybunału I Instancji z 8 listopada 1828 r.). Chodziło o przepisy oddziału I działu II tytułu IV księgi II (art. 653-673).

${ }^{108}$ Archiwum Uniwersytetu Jagiellońskiego, sygn. WP I 58, s. 551-552 (opinia Wydziału Prawa UJ z 5 maja 1829 r.); ANK, Archiwum Wolnego Miasta Krakowa, sygn. 29/200/1666, s. 359-360 (odpis opinii). Opinię wydali Antoni Matakiewicz, Józef Jankowski, Ferdynand Kojsiewicz, Mikołaj Hoszowski i Józef Słoniński. 
muru przez biegłych ${ }^{109}$. Warto dodać, że rozwiązanie z art. 654 wiązało się z art. $681 \mathrm{KN}$, który nakazywał, aby ściek z dachów (okap) kierować wyłącznie na swój grunt ${ }^{110}$.

\section{Sprawa Słotwińskiego przeciwko Schwartzowej}

Granic korzystania z muru dotyczyła sprawa krakowskiego adwokata i profesora prawa F. Słotwińskiego, zamieszkałego przy ulicy Szerokiej pod L. 78 (obecnie pl. Dominikański 5), przeciwko Juliannie Schwartzowej, zamieszkałej przy ulicy Grodzkiej 82 (obecnie ul. Grodzka 28) ${ }^{111}$, reprezentowanej przez Józefa Jankowskiego (pojawiała się sądzie „w asystencji” męża Jana Schwartza). Stan faktyczny przedstawiał się następująco. W 1818 r. Słotwiński kupił kamienicę L. 78 od Antoniego i Marianny Szreterczów „W drodze licytacji publicznej”. Jak przekonywał, od „niepamiętnych czasów” byli oni w ,spokojnej posesji” służebności „nie podwyższania muru, światła, widoku i świeżego powietrza”. Były one „niezawisłe od łaski” właścicielki obciążonej służebnością kamienicy pod L. 82, która musiała powstrzymywać się od wykonywania szeregu uprawnień właścicielskich. Tymczasem Słotwiński powziął wiadomość, że małżonkowie Schwartz noszą się z zamiarem przystawienia widermachu - do muru granicznego będącego jego własnością ${ }^{12}$.

Jako że planowana budowla miała sięgać wysokości „powyżej dwóch pięter” (,powyżej tranżety”), pojawiła się realna groźba, że dojdzie do utraty przez Słotwińskiego dostępu do widoku (,,południowego słońca i zdrowego powietrza"). Co więcej, widermach mógł stanowić istotne zagrożenie dla

${ }^{109}$ ANK, Archiwum Wolnego Miasta Krakowa, sygn. 29/200/1666, s. 335-338 (wyrok Sądu III Instancji z 15 października 1829 r.). Sąd wydelegował sędziego Józefa Pareńskiego i biegłych architektów, Franciszka Sapalskiego i Jakuba Czernińskiego, którzy mieli „ułożyć rysunek muru” oraz ustalić, czy framugi i gzymsy posiadały rzeczone właściwości fizyczne.

${ }^{110}$ J. J. Delsol, Zasady..., s. 480. Dla autora prawo ścieku nie był służebnością, lecz „prostym uświęceniem każdej własności”.

${ }^{111}$ Plan miasta Krakowa..., s. 12 (oraz sekcja 41 - plan z identyfikacją adresów).

112 ANK, Archiwum Wolnego Miasta Krakowa, sygn. 29/200/1717, s. 81 („Wywód Uciążliwości wyroku Sądu Pokoju z dn. 1 lipca 1820 r. między Feliksem Słotwińskim appelującym a Julianną Schwartzową appelowaną, zapadłego"). Nie ma pewności, czy przystawiając budynek Schwartzowie chcieli skorzystać z prawa zamknięcia okien Słotwińskiego, co z pewnością przysługiwało sąsiadowi, który nabył środkowość muru. Zob. przyp. 75. 
konstrukcji muru, który miał bardzo słabe fundamenty, a w dwóch miejscach był już uszkodzony („rozpadnięty”). Dlatego dla Słotwińskiego niemiłym zaskoczeniem było zezwolenie komisji policyjno-budowlanej na podwyższenie muru, co Wydział Policji zaaprobował pod warunkiem wzmocnienia fundamentów i pogrubienia muru; w ocenie komisji prace Schwartzów nie mogły wpłynąć negatywnie na korzystanie ze służebności przez Słotwińskiego. Ten ostatni wskazywał, że rozstrzyganie spraw posesoryjnych (w tym o „spokojne posiadanie”) należy jednak do sądów pokoju (,,sądownictwo cywilne”), a nie organów rządowych; ponadto twierdził, że „czynienie przeciwko służebności należy do petitorium" ${ }^{113}$.

Słotwiński pozwał Schwartzową przed sąd pokoju, domagając się utrzymania w „spokojnym posiadaniu” służebności. Żądanie zostało oddalone, gdyż Słotwiński nie udowodnił „odjęcia światła” przez pozwaną. Słotwiński kwestionował liczne czynności sądu, w tym posłużenie się biegłymi, jako że posiadanie służebności „od niepamiętnych czasów” nie było zaprzeczone; zaś nawet gdyby było inaczej, to sąd mógłby jedynie skorzystać z zeznań świadków. Konkludując, pozbawienie go służebności widoku było tak oczywiste, że domagał się jej natychmiastowego przywrócenia ${ }^{114}$.

Odpowiedź Józefa Jankowskiego, pełnomocnika Schwartzowej, była dość ogólnikowa i opierała się na dwóch twierdzeniach. Po pierwsze, w sprawie doszło do ugody (,dobrowolnego ułożenia się”), zaś Słotwiński domagał się jedynie, aby widermach nie przewyższał ganku jego domu, co „ubliżałoby służebności światła”. Co bardziej interesujące, Schwartzowa zaprzeczała, aby w ogóle była ograniczona służebnością. Uważała, że służebność polegająca na powstrzymywaniu się przez podmiot nią obciążony od budowania powyżej pewnej wysokości (,zabronienie budowania tylko do oznaczonej wysokości”) jest służebnością ciągłą niewidoczną (art. 688-689 $\mathrm{KN}$ ), a więc może być ustanowiona wyłącznie w drodze umowy (,na mocy

${ }^{113}$ Ibidem, s. 81-82 (,Wywód Uciążliwości wyroku Sądu Pokoju z dn. 1 lipca 1820 r. między Feliksem Słotwińskim appelującym a Julianną Schwartzową appelowaną, zapadłego"); decyzja Wydziału Policji z 20 kwietnia 1820 r. nr 1506. Również Senat Rządzący reskryptem z 7 lipca 1820 r. nr 2207 DGS uznał, że problematyka służebności nie leży w gestii władz policyjnych.

${ }^{114}$ Ibidem, s. 82-83. Słotwiński dodawał, że nawet gdyby przyjąć, iż w rozpoznaniu sporu posesoryjnego mogą brać udział biegli, to konieczne byłoby ich prawidłowe wezwanie, a także partycypacja w ich czynnościach także ze strony sędziego pokoju i pisarza sądowego. 
tytułu”, art. $691 \mathrm{KN})$. Ponieważ Słotwiński nie przedstawił żadnej umowy, przegrał sprawę wobec zaprzeczenia drugiej strony. Jankowski powoływał się również na art. $657 \mathrm{KN}$, że współwłaścicielowi muru środkowego przysługuje prawo umieszczania belek aż do połowy jego grubości. Wskazał także na art. $662 \mathrm{KN}$ głoszący, że wszelkie przystawienia do muru środkowego są dopuszczalne za zgodą współwłaściciela, zaś w razie jej nieuzyskania rozstrzygająca miała być opinia biegłych (którą zresztą „,appelowana” uzyskała, o czym świadczył protokół komisji biegłych i pozwolenie Urzędu Budowniczego). Jej zarzut „bezgruntowności appelacji Słotwińskiego” odnosił się też do zastrzeżeń dotyczących zbyt małej odległości widermachu. Wynosiła ona wszakże siedem łokci, zaś art. 678-679 KN mówiły o minimum sześciu decymetrach (2 stopy) odległości od obiektu, na który spogląda właściciel - ,z boku bądź ukośnie" ${ }^{115}$.Opierając się na opinii sędziego sprawozdawcy, zapadł wyrok Sądu Apelacyjnego, który stwierdził, że wobec brzmienia art. 657-660 KN Schwartzowa nie tylko może podwyższyć mur, ale także - w granicach przysługującego jej prawa własności - przystawiać do niego elementy budowlane. Co do wysokości deklarowanego przez nią widermachu orzekł, iż nie krępuje jej na rzecz domu Słotwińskiego żadna „służebność budowania tylko do oznaczonej wysokości”. Znalazł tu zresztą zastosowanie wspomniany art. $691 \mathrm{KN}$ (Słotwiński nie udowodnił tytułu itd.). Schwartzowa zaakceptowała przy tym ustalenia biegłych w sprawie parametrów technicznych widermachu. Uwzględnił je Sąd Apelacyjny, który nakazał, aby wysokość ściany widermachu stawianego przez Schwartzową „od ściany Zamoyskiego w winklu muru granicznego ze Słotwińskim od strony wchodowej” nie przekraczała sześciu sążni miary wiedeńskiej licząc „od powierzchni ziemi aż do wierzchu dachowego"116.

Z kronikarskiego obowiązku należy odnotować, że opinię w sprawie wydał Wydział Profesorów i Doktorów UJ, jednakże ze względu na to, że oba wyroki - sądu pokoju i Sądu Apelacyjnego - „nie były zgodne w treści”,

${ }^{115}$ Ibidem, s. 85-87 (pismo J. Schwartzowej do Sądu Apelacyjnego). W przypadku „widoków prostych" odległość wynosiła 19 decymetrów, czyli 6 stóp. W piśmie wspomniano też o 7 komisjach i „tyluż superrewizjach”, w których musiała brać udział appelowana; Schwartzowa poniosła też dodatkowy wydatek 3000 złp, z powodu zablokowania prac budowlanych.

${ }^{116}$ Ibidem, s. 221-224 (wyrok Sądu Apelacyjnego z 27 lipca 1820 r.). Wysokość drugiego muru stawianego w podworcu Schwartzowej, „,w punkcie stykania się onego do wspólnego muru ze Słotwińskim” - nie mogła przewyższać 4 1/2 sążni wiedeńskich i 2 stóp. 
wniesienie skargi kasacyjnej do Sądu III Instancji było możliwe bez wymogu pozytywnej opinii fakultetu prawnego ${ }^{117}$.

\section{Sprawa Hatzfelda przeciwko Wilczyńskiej}

Dobrą okazję do rozważań nad sposobami korzystania ze służebności stanowi kazus Franciszka Hatzfelda, byłego kancelisty przy Inspektoracie Dochodów Publicznych, zamieszkałego w Krakowie pod L. 491 (obecnie ul. św. Tomasza 15), którego pełnomocnikiem był Słotwiński, przeciwko Jadwidze $1^{\circ} \mathrm{v}$. Wyżałkiewiczowej, $2^{\circ}$ v. Wilczyńskiej, zamieszkałej pod L. 492 (obecnie ul. św. Jana 5) ${ }^{118}$. Domagała się ona natychmiastowego wyburzenia („zniesienia”) kloak wymurowanych pod murem granicznym ze względu na „zasłonięcie widoku”. Po zapoznaniu się z opinią prokuratora Sąd Apelacyjny zatwierdził wyrok Trybunału i nakazał Hatzfeldowi rozebranie „wystawionych wbrew planowi” kloak oraz ich przeniesienie „na miejsce wskazane planem", czyli pod mur domu pod L. 490 (obecnie ul. św. Tomasza 17) ${ }^{119}$.

Obrona Hatzfelda przeciwko żądaniom Wilczyńskiej, sformułowana przez jego pełnomocnika (F. Słotwiński) w skardze incydentalnej, opierała się na twierdzeniu, że w istocie nie przysługuje jej służebność widoku. W wyroku Trybunał stwierdził, że wykazała ona „słuszność swych żądań” przy pomocy dokumentów, w szczególności zaś protokołu sesji sądu pokoju z 14 lipca 1831 r., podczas której Hatzfeld miał uznać istnienie służebności widoku, którą zniweczył wymurowaniem kloak ${ }^{120}$.

${ }^{117}$ Archiwum Uniwersytetu Jagiellońskiego, sygn. WP I 58, s. 67-68 (opinia Wydziału Prawa UJ z 18 lipca 1821 r.). „Według przepisów Konstytucji odwołanie się wprost miało miejsce". Opinię wydali A. Krzyżanowski, Augustyn Boduszyński, Mikołaj Hoszowski, ks. Mateusz Dubiecki i Antoni Matakiewicz. Wniosek wpłynął na dziennik podawczy 3 listopada 1820 r. (do nr 740).

${ }^{118}$ Plan miasta Krakowa.., s. 19 (oraz sekcja 41-plan z identyfikacją adresów).

${ }^{119}$ ANK, Archiwum Wolnego Miasta Krakowa, sygn. 29/200/1742, s. 881-883 (wyrok Sądu Apelacyjnego z 29 września 1835 r.); wyrok Trybunału I Instancji z 18 czerwca 1834 r. Pełnomocnikiem Wilczyńskiej był S. Boguński.

${ }^{120}$ Pozostałe dokumenty: protokół komisji budowniczej z 22 kwietnia 1829 r; plan budowy kloak z 1 czerwca 1829 r.; rozporządzenie Wydziału Spraw Wewnętrznych z 5 września 1833 r. nr 3795; wyroki: sądu pokoju z 18 lipca 1831 r.; Sądu III Instancji z 23 stycznia 1832 r. (zaoczny), z 5 grudnia 1833 r. (posesoryjny); oraz ibidem, sygn. 29/200/1743, s. 479-481 (wyrok Sądu Apelacyjnego z 5 listopada 1831 r.). Zob. ibidem, s. 483-484 
W związku z tym Trybunał nie przyjął wniosku o ,inkwizycję ze świadków", twierdząc, że skarga incydentalna Hatzfelda w sprawie zniesienia służebności ma bezpośredni związek z żądaniem Wilczyńskiej dotyczącym usunięcia kloak. Zdaniem Hatzfelda było to rozumowanie błędne, gdyż protokół komisji, podobnie jak wyrok sądu pokoju, wcale nie dowodziły, aby zrzekł się on prawa wymurowania kloak; co więcej, mąż powódki Stanisław Wilczyński oświadczył, że „nie ma nic przeciw fabryce”, pod warunkiem prowadzenia robót $\mathrm{w}$ granicach określonych prawem, a także naprawienia szkód wyrządzonych w konstrukcji muru środkowego i dachu - do czego zresztą nie doszło. Zrzeczenia się przez Hatzfelda „prawa budowania na swoim dziedzińcu" nie dowodził też fakt, że pierwotnie miał on zamiar poprowadzenia kloak przy murze granicznym domu pod L. 490, o czym świadczył plan budowy z 1800 r. (Słotwiński przekonywał, że „o służebności rozstrzyga prawo, a nie plany”). Kluczowe było zaś ustalenie, czy Wilczyńska nabyła służebność polegającą na możliwości zakazania Hatzfeldowi budowania na jego własnym dziedzińcu. Nawet przy założeniu, że istotnie do tego doszło, to fakt istnienia kloak, choćby w innej części dziedzińca, był stanem sprzecznym z treścią służebności, a więc musiało dojść do jej utraty przez Wilczyńską. Pełnomocnik Wilczyńskiej przekonywał też o istnieniu służebności cloacae non aedificandi, zdaniem Słotwińskiego nieznanej prawu rzeczowemu (a przecież „służebność nie może być domniemywana"); w razie braku zasiedzenia art. $690 \mathrm{KN}$ wymagał dla nabycia służebności tytułu, prawo hipoteczne zaś - wpisu do ksiąg hipotecznych, czego Wilczyńska nie dopełniła. Na rzecz wygaśnięcia „niepraktykowanej służebności” przemawiało także ,zasłonięcie okien przez ganki” oraz relacje świadków, którzy przekonywali, że ani Wilczyńska, ani jej poprzednicy nigdy nie mieli służebności. Z drugiej strony Wilczyńska nie wykazała, kiedy i przez jaki czyn prawny Hatzfeld i jego poprzednicy prawni zostali ograniczeni w prawie wymurowania kloak. Nawet gdyby uznać istnienie służebności widoku, to przecież Wilczyńska nie mogła na niej ustanowić drugiej służebności cloacae non aedificandi - bo to „wcale co innego”, co przyznał zresztą Trybunał (zakaz budowania kloak był przejawem realizacji służebności widoku, formą korzystania z niej, a nie odrębnym uprawnieniem). Odnośnie do wyroków posesoryjnych, które zresztą przegrał, Hatzfeld twier- 
dził, że nie mogą być uwzględnione w sprawie petytoryjnej, zaś podobnie niekorzystne dla niego decyzje (,akty administracyjne”) władz rządowych nie mogą „ubliżać wyrokom sądowym” (Wydział Spraw Wewnętrznych wstrzymał egzekucję swoich uchwał do czasu rozstrzygnięcia sądowego). Sąd pokoju był tak mocno przekonany o prawdziwości twierdzeń Wilczyńskiej, że odrzucił wniosek Hatzfelda w sprawie przesłuchania świadków; według Słotwińskiego skarga negatoryjna jego klienta nie miała związku ze skargą główną Wilczyńskiej, gdyż to ona powinna wykazać tytuł prawny do służebności widocznej (,,jawnej”), nabywanej jedynie „,przez tytuł” (dowodem mógł być wpis do księgi wieczystej) bądź 30-letnie posiadanie (art. 690 $\mathrm{KN}$ ). Ponieważ Wilczyńska nie dopełniła powyższych przesłanek, jej sprawa powinna zostać oddalona w drodze petytoryjnej, z żądaniem służebności widoku $^{121}$. Odpowiedź pełnomocnika Wilczyńskiej (S. Boguński) zasadzała się na całkowitej negacji zarzutów Hatzfelda ${ }^{122}$.

\section{Sprawa Majdrowiczowej przeciwko Luxembergowi}

Interesujący przebieg miała także sprawa Antoniny z Różańskich $1^{\circ} \mathrm{v}$. Majdrowiczowej, $2^{\circ}$ v. Lassotowej, wdowy po Kazimierzu Majdrowiczu, działającej też w imieniu małoletnich dzieci, Marcina i Antoniego, zamieszkałej na Kazimierzu pod L. 102 (obecnie ul. Józefa 10), reprezentowanej przez Onufrego Męcińskiego, przeciwko Berlowi Luxembergowi, zamieszkałemu tamże pod L. 103/104 (obecnie ul. Józefa 12) ${ }^{123}$, którego adwokatem był Józef Kozłowski. Odtworzenie jej przebiegu pozwala spojrzeć na różnorakość uprawnień wynikających ze służebności. Jeśli chodzi o genezę sporu, należy powiedzieć, że Majdrowiczowie nabyli kamienicę pod L. $102 \mathrm{w}$ drodze licytacji w 1801 r., czyli jeszcze pod rządami prawa austriackiego $^{124}$.

${ }^{121}$ ANK, Archiwum Wolnego Miasta Krakowa, sygn. 29/200/1742, s. 885-890 („Uciążliwości Franciszka Hatzfeld przeciwko Jadwidze Wilczyńskiej”).

122 Ibidem, s. 891-892 („Odpowiedź Wilczyńskiej”). Jak wspomniano wyżej, sąd uwzględnił argumentację Boguńskiego.

${ }^{123}$ Plan miasta Krakowa..., s. 25 (oraz sekcja 57 - plan z identyfikacją adresów).

${ }^{124}$ Umowa kupna-sprzedaży budynku i pustek pod L. 103/104 z 10 lutego 1801 r. zawarta między Antoniną z Kromerów $1^{\circ}$ v. Zakulską, $2^{\circ}$ v. Michalczewską a Luxembergiem, przyjęta przez kuratora małoletnich, wciągnięta do akt magistratu Kazimierza 6 maja $1801 \mathrm{r}$. 
Wydając wyrok, Sąd Apelacyjny wskazał, że wedle tegoż prawa każdą sprzedaż licytacyjną nieruchomości powinno poprzedzić publiczne wezwanie wierzycieli hipotecznych („kredytorów”) oraz innych osób mających jakiekolwiek roszczenia pod rygorem ich utraty. Wezwania dokonano prawidłowo, jednakże Luxemberg nie zgłosił („nie likwidował”) swojej służebności. Stąd też sąd oddalił jego żądania dotyczące: prawa „dostawienia się” do muru kamienicy Majdrowiczów; wyprowadzenia na ich grunt „okien widok niezacieniony mieć mogących"; prawa przechodu dla niego i robotników uczestniczących w pracach budowlanych; prawa przewozu rzeczy oraz brania wody ze studni należącej do kamienicy L. 102 „dla domowej potrzeby i fabryki” (prace budowlane). Stwierdził też prawidłowość nabycia przez Majdrowiczów własności kamienicy na warunkach określonych aktem licytacji ${ }^{125}$.

Takie rozstrzygnięcie Sąd Apelacyjny podtrzymał w kolejnym wyroku, wydanym w związku z wniesioną przez Luxemberga „oppozycją"126. Dodał przy okazji, że w okresie 1808-1818 Luxemberg nie wykonywał żadnej ze służebności, dlatego nie spełnił wymogów z art. 608 cz. III kodeksu galicyjskiego (upływ 3 lat i 6 tygodni) oraz art. $2281 \mathrm{KN}$, koniecznych dla zasiedzenia służebności ${ }^{127}$. Jeszcze wcześniej Trybunał orzekł, że co prawda służebności nie zostały zamieszczone w warunkach sprzedaży licytacyjnej, ale w toku procesu Majdrowiczowa wskazywała na ich sprzeczność z „,rozporządzeniami politycznymi”, a przecież Luxembergowi „służyło prawo prywatne" ${ }^{28}$. Co ciekawe, pełnomocnik Luxemberga powoływał się na art.

${ }^{125}$ ANK, Archiwum Wolnego Miasta Krakowa, sygn. 29/200/1714, s. 861-864 (wyrok Sądu Apelacyjnego z 11 maja 1819 r.). W kwestii zadośćuczynienia za ,zainsynuowanie” tych praw podczas licytacji sąd odesłał Majdrowiczów do „drogi osobnego procesu".

${ }^{126}$ Ibidem, sygn. 29/200/1715, s. 675-676 (wyrok Sądu Apelacyjnego z 7 października 1819 r.). Koszty uległy wzajemnemu zniesieniu. Zob. pisma w sprawie: s. 679-685 („Notta Oppozycyjna ze strony Berla Luxemberga”); s. 692-692 („Odpowiedź Antoniny Maydrowiczowey na Oppozycyę Berla Luxemberg przeciwko wyrokowi Sądu Apelacyjnego 11 maja 1819 r. wydanemu założoną wniesiona”).

${ }^{127}$ Art. 2281: „Przedawnienia zaczęte w czasie ogłoszenia niniejszego tytułu, urządzone będą stosownie do praw dawnych. Jednakże przedawnienia wtenczas zaczęte, i dla których potrzeba by jeszcze według praw dawnych więcej niż lat trzydziestu, rachując od tegoż samego czasu, dopełnione będą upłynieniem lat trzydziestu”.

128 ANK, Archiwum Wolnego Miasta Krakowa, sygn. 29/200/1967, s. 2235-2238, 2241-2243 (wyrok Trybunału I Instancji z 30 grudnia 1818 r.). 
266 cz. II kodeksu galicyjskiego, że służebność ustaje z chwilą ustania przyczyny jej powstania ${ }^{129}$.

Sprawa trafiła ostatecznie do Sądu III Instancji, który po analizie „,prawnych powodów wyroku” Sądu Apelacyjnego zatwierdził go w całości ${ }^{130}$. Sąd nie wziął pod uwagę argumentacji Luxemberga, że we wszelkich ustawodawstwach obowiązują identyczne wymogi przy ,ustanawianiu, nabywaniu i znoszeniu praw" - np. w razie istnienia hipoteki umownej przy dokonywaniu wpisu należało powiadomić stronę i uzyskać jej zezwolenie (identycznie przy znoszeniu); w prawie austriackim istniał obowiązek ,zalikwidowania” (zgłaszania) praw hipotecznych przy licytacji, pod rygorem ich utraty ${ }^{131}$.

\section{Sprawa xx. Mansjonarzy przeciwko Samelsonowi}

Znaczny stopień zawiłości przedstawiała sprawa xx. Mansjonarzy przy kościele Mariackim, przeciwko Maurycemu Samelsonowi (Samelsohnowi), właścicielowi nabytego od Katarzyny Bartschowej domu pod L. 55 (obecnie ul. Sienna 4), którego reprezentował Wawrzyniec Soświński. Samelson domagał się przyznania służebności widoku i ścieku na należącym do zakonników budynku pod L. 56 (obecnie ul. Sienna 6) ${ }^{132}$. Zaprzeczali oni istnieniu służebności, twierdząc, że mur jest „częścią budowli Mansjonarzy”, co potwierdził Walenty Bartsch w 1818 r. Mur nie był też wpisany w aktach hipotecznych kamienicy pod L. 55. Pierwszym wątkiem, który badały sądy, było ustalenie, czy przy regulacji hipoteki nastąpiło zgłoszenie służebności. Zdaniem Samelsona Mansjonarze nie postarali się o wpis ostrzeżenia o służebności do ksiąg hipotecznych, a ponieważ spór dotyczył praw rzeczowych, nie mogli występować przeciwko niemu jako osobie trzeciej (,nabywca,

129 Ibidem, s. 2245-2247 (,Wywód i Konkluzja ze strony Starozakonnego Berla Luxemberga”); s. 2249-2251 („Obrona ze strony Sukcessorów śp. Kazimierza Majdrowicza pozostałych, pozwanych, przeciwko Starozakonnemu Berl Luxembergowi powodowi”).

${ }^{130}$ Ibidem, sygn. 29/200/1656, s. 99-100 (wyrok Sądu III Instancji z 8 lutego 1820 r.). Sąd zdecydował też o zniesieniu kosztów.

${ }^{131}$ Ibidem, s. 103-105 (,Wywód Uciążliwości ze strony Luxemberga”). Luxemberg zaprzeczał, aby nie używał służebności, co mógł wykazać ,inkwizycją ze świadków”. Wśród zarzutów wskazywał także: nie został przypozwany; nie wykreślono wpisu hipotecznego; nie doszło do przedawnienia służebności. Pytał, czy dopuszczalne jest rozciąganie skutków czynności między dwoma stronami na osobę trzecią. Twierdził, że za wyrokiem Sądu Apelacyjnego nie przemawia ,ani prawo, ani słuszność”.

${ }^{132}$ Plan miasta Krakowa..., s. 12 (oraz sekcja 41 - plan z identyfikacją adresów). 
z którym nie mieli żadnych czynności”). Samelson działał też w zaufaniu do ksiąg wieczystych (,spuścił się na rzetelność wykazu hipotecznego”) ${ }^{133}$.

Sąd III Instancji uznał, podobnie jak Sąd Apelacyjny, że obowiązek złożenia wniosku o wpis ostrzeżenia hipotecznego spoczywał na Samelsonie; innymi słowy, Mansjonarze nie musieli czynić ostrzeżenia o cudzej służebności na swojej nieruchomości. To Samelson winien zasięgnąć informacji u Bartschowej lub sprawdzić w Urzędzie Hipotecznym, czy służebność jest odnotowana w hipotece i w jakiej drodze powstała (umowa bądź zasiedzenie). Tę część „pierwiastkowego powództwa” Samelsona sądy zgodnie odrzuciły $^{134}$. Samelson wskazywał też, iż spór o zamurowanie okna i ściek wody deszczowej toczył się już od 1819 r. na drodze administracyjnej. Mansjonarze przyznawali, iż w tym czasie poprzedni właściciel kamienicy L. 55 samowolnie „otworzył okno” w murze środkowym oraz skierował ściek na ich posiadłość. Dlatego wnieśli „na drodze administracyjnej” skargę do Wydziału Policji, który jednak odesłał ich na drogę sądową ${ }^{135}$.

Głównym przedmiotem rozważań sądów było pytanie, czy Samelson mógł wybić „okna do patrzenia”, czy jedynie „otwory dające dostęp światła” skierowane na dziedziniec Mansjonarzy. Odpowiedź zależała od ustalenia, czy mur, w którym poprzedni właściciel wybił okno, jest środkowy, czy należy wyłącznie do Samelsona. Przy wspólności brak zgody współwłaściciela, czyli Mansjonarzy, skutkował niedopuszczalnością wykucia otworu, jak też okna. W przeciwnym razie było to możliwe, jednak ,z ograniczeniami prawnymi” (art. 675-680 KN). Aby uzyskać niezbędną wiedzę, Sąd Apelacyjny zlecił ekspertyzę biegłym, którzy nie tylko mieli zbadać, czy mur jest środkowy (badając m.in. „znaki nieśrodkowości”), ale także ustalić przestrzeganie parametrów technicznych wskazanych w art. 676-680 KN (,Jaka

${ }^{133}$ ANK, Archiwum Wolnego Miasta Krakowa, sygn. 29/200/1677, s. 495, 497-498 („Wywód Rekursu ze strony Maurycego Samelsona przeciwko XX. Mansjonarzom przy kościele Panny Maryi”); s. 503-504 („Odpowiedź XX. Mansyonarzy kościoła P. Maryi przeciwko Samelsohnowi”); s. 508-510 (relacja sędziego sprawozdawcy z 15 czerwca 1836 r.). Zdaniem Samelsona Mansjonarzom służyło tylko roszczenie osobiste do sukcesorów Walentego Bartscha o wynagrodzenie szkód.

${ }^{134}$ Ibidem, s. 503-504 („,Odpowiedź XX. Mansyonarzy kościoła P. Maryi przeciwko Samelsohnowi”). Sąd stwierdził, że nie ma przepisu nakazującego odnotowywanie w księgach hipotecznych faktu, że sąsiad nie ma na niej służebności.

135 Ibidem, s. 495 („Wywód Rekursu ze strony Maurycego Samelsona przeciwko XX. Mansjonarzom przy kościele Panny Maryi”); s. 501-502 („Odpowiedź XX. Mansyonarzy kościoła P. Maryi przeciwko Samelsohnowi”). 
jest wysokość wybitego okna, licząc od podłogi pomieszczenia, które ma oświetlać?”; „Czy widok prosty z okien domu L. 55 na dziedzictwo domu L. 56 wynosi więcej niż 19 decymetrów, czyli 6 stóp odległości, rachując od zewnętrznej powierzchni muru?”). Ostatnie pytanie brzmiało: „Czy ściek wód deszczowych z domu L. 55 następuje na nieruchomość jego właściciela, czy sąsiednią?" ${ }^{136}$. Biegli zostali wyznaczeni na podstawie art. 302 i 305 $\mathrm{KPC}^{137}$.

Wincenty Szpor, adwokat Mansjonarzy, celem ułatwienia sądom rozstrzygnięcia sporu postawił kilka podstawowych pytań. Czy okno otwarte na cudze dziedzictwo jest służebnością - tak, ale czy należy je uważać za służebność ustawową czy umowną? Szpor twierdził, że służebność widoku nie może być uważana za powstającą z mocy prawa, dlatego Trybunał w swych wyrokach błędnie powoływał się na art. 675-677 KN, podczas gdy znajdowały zastosowanie ograniczenia z art. 678-680 KN. Szpor akcentował też różnice między służebnościami ustawowymi i umownymi, bo to $\mathrm{w}$ ramach tych ostatnich właściciel obciążony służebnością musiał się powstrzymywać od działań, które mogły utrudniać korzystanie ze służebności władnącej (art. $701 \mathrm{KN}$ ). Jednakże w sprawie nie zawarto umowy ustanawiającej służebność, nie doszło też do jej zasiedzenia (art. $690 \mathrm{KN}$ ). Stąd też kluczowe było ustalenie, czy okno miało widok prosty („,bez żadnej odległości”) na dziedzictwo Mansjonarzy, a jeżeli tak, to czy przestrzegane były postanowienia art. $678 \mathrm{i} 680 \mathrm{KN}^{138}$.

Osobny wątek stanowiło podejrzenie prowadzenia przez W. Bartscha, poprzedniego właściciela kamienicy pod L. 55, prac wokół muru, które naruszały art. 675 i $681 \mathrm{KN}$. Chodziło o wymurowanie okna altanowego skierowanego na podwórze L. 56, wykonanie framug i inne przeróbki. Samelson bronił się przed odpowiedzialnością z tego tytułu, twierdząc, że kamienica przeszła w jego ręce jako „osoby trzeciej”, z którą Mansjonarze nie mieli

${ }^{136}$ Ibidem, s. 491-493 (wyrok Sądu III Instancji z 13 października 1836 r.); wyrok Trybunału I Instancji z 4 kwietnia 1834 r.; wyrok Sądu Apelacyjnego z 28 listopada 1834 r. Sąd, jak widać, literalnie odczytał wymogi kodeksowe w sprawie parametrów technicznych.

${ }^{137}$ Ibidem, s. 495-496 („Wywód Rekursu ze strony Maurycego Samelsona przeciwko XX. Mansjonarzom przy kościele Panny Maryi”). Biegłymi byli architekci T. Żebrawski, Ignacy Hercok i Hermanowski, którym towarzyszył sędzia Felicjan Dudrewicz.

${ }^{138}$ Ibidem, s. 501-504 („,Odpowiedź XX. Mansyonarzy kościoła P. Maryi przeciwko Samelsohnowi”). Osobne pytanie dotyczyło prawidłowego zorganizowania ścieku, zgodnie $\mathrm{z}$ art. $681 \mathrm{KN}$. 
żadnych czynności prawnych (,prawa ubezpieczającego”), a to ze względu na przepisy prawa hipotecznego. Sędzia sprawozdawca Wincenty Gołuchowski dostrzegł jeszcze inne niejasności w sprawie. Samelson powoływał się na opinię Urzędu Budownictwa, że Bartsch miał prawo wybicia okien, ponieważ mur należał do L. 55 - w tej sytuacji jednak, wobec brzmienia art. 676-677 i 681 KN, należało oddalić skargę Mansjonarzy. Sprawozdawca zalecał więc sięgnięcie do opinii biegłych, która powinna potwierdzić istnienie „znaków nieśrodkowości” oraz ustalić, czy przy okazji przebudowy (restauracji) kamienicy doszło do wybicia okna w podwyższonej części muru; a także, czy okno, zgodnie z art. $677 \mathrm{KN}$, znajduje się na odpowiedniej wysokości - w stosunku do poziomu podłogi pomieszczenia, które jest oświetlane ${ }^{139}$.

\section{Sprawa Adlera przeciwko Gajdzińskiemu}

Sprawa pomiędzy zamieszkałym w kamienicy na Kazimierzu pod L. 98 (obecnie ul. Krakowska 20) kupcem Jakubem Adlerem, którego adwokatem był Jan K. Rzesiński, a Józefem Gajdzińskim, właścicielem domu pod L. 99 (obecnie ul. Józefa 4) ${ }^{140}$, reprezentowanym przez S. Boguńskiego, dotyczyła w głównej mierze ważności umowy odnoszącej się do ustanowienia służebności. W 1831 r. obaj sąsiedzi zawarli umowę, w formie aktu notarialnego, na podstawie której Adler zgodził się na wybicie w murze granicznym jednego „okna dla widoku”, pod warunkiem zaopatrzenia go w okiennice i żelazną kratę. W zamian Gajdziński zobowiązał się do wykonania trzech framug w murze od strony kamienicy sąsiada, co miało umożliwić Adlerowi „używanie muru środkowego”. Wkrótce Gajdziński uzyskał, ale jedynie w formie ustnej, zgodę na wybicie dodatkowego okna. Obok umowy spisanej przez notariusza funkcjonowała więc także umowa ustna, która zresztą natychmiast została wykonana. Ponieważ okazało się, że z powodu „twardości murów” wybicie framug jest niemożliwe, Gajdziński zwrócił się do sąsiada o zwolnienie go z wykonania tego punktu ,intabulowanego kontraktu", na co uzyskał - jak zapewnił - jego zgodę; analogiczne porozumienie zawarto w kwestii zamontowania ,żelaznych okiennic". Wkrótce jednak Adler, jak twierdził Gajdziński - „uwiedziony chęcią procesowania się i upatrujący dla siebie zapewne nowych korzyści”, pozwał sąsia-

\footnotetext{
${ }^{139}$ Ibidem, s. 505-510 (relacja sędziego sprawozdawcy z 15 czerwca 1836 r.).

${ }^{140}$ Plan miasta Krakowa..., s. 25 (oraz sekcja 57 - plan z identyfikacją adresów).
} 
da przed Trybunał, zarzucając mu ,nie dotrzymanie kontraktu”. Miało to polegać na niezrobieniu framug i ,wyprowadzeniu” aż trzech okien bez krat (zamiast jednego), a także „poprowadzeniu ganków przy oknach”"141. Stąd też Adler domagał się rozwiązania umowy pisemnej, zamurowania trzech „,nielegalnych okien” oraz wynagrodzenia szkód i przyznania kosztów procesu ${ }^{142}$.

Trybunał dopuścił „naoczne obejrzenie przedmiotu sporu” przez biegłych przysięgłych, przy udziale sędziego (Felicjan Dudrewicz). Ich rolą było ustalenie („obejrzenie i wyjaśnienie”) faktycznej treści służebności, pod kątem okoliczności ,ponad osnowę umowy okazujących się"143. Rozpatrujący apelację incydentalną Sąd Apelacyjny badał kwestię dopuszczalności dowodu z przysięgi (świadków lub biegłych) przeciwko osnowie dokumentu urzędowego, jakim był akt notarialny. Sąd stwierdził naruszenie art. $1341 \mathrm{KN}^{144}$, ponieważ Gajdziński nie przedstawił aktu pisemnego dowodzącego zmianę lub ograniczenie treści służebności ustanowionej przez Adlera w drodze umowy pisemnej, a wszakże „początek dowodu był przez pismo”"145. Dla większej jasności trzeba dodać, że prawo widoku należy do służebności ciągłych i widocznych, a więc może być ustanawiane (obok możliwości zasiedzenia) wyłącznie przez tytuł. Pod tym pojęciem doktryna rozumiała „każdy czyn prawny mogący przenieść własność lub jedną z jej oderwanych

${ }^{141}$ ANK, Archiwum Wolnego Miasta Krakowa, sygn. 29/200/1758, s. 877-880 („Wywód Uciążliwości ze strony Józefa Gajdzińskiego przeciwko Jakubowi Adlerowi”); akt notarialny sporządzony przez notariusza Antoniego Matakiewicza 5 maja $1831 \mathrm{r}$.

142 Ibidem, s. 881-882 („Odpowiedź z strony P. Adlera przeciwko Józefowi Gajdzińskiemu").

${ }^{143}$ Ibidem, s. 873-874 (wyrok Sądu Apelacyjnego z 9 marca 1837 r.); wyrok Trybunału I Instancji z 14 stycznia $1837 \mathrm{r}$.

${ }^{144}$ Art. 1341: „Powinien być zawarty akt przed notariuszami, albo z podpisem prywatnym o wszelkie rzeczy, które przenoszą sumę wartości 150 franków, choćby nawet na skład dobrowolny. I żaden dowód przyjmowany nie jest przez świadków przeciw temu, albo nad to, co akta obejmują, ani na to, co byłoby przytaczane, że mówione było przed, w czasie lub po skończonych aktach, choćby nawet szło o sumę lub wartość mniejszą nad 150 franków".

145 ANK, Archiwum Wolnego Miasta Krakowa, sygn. 29/200/1758, s. 874-875 (wyrok Sądu Apelacyjnego z 9 marca 1837 r.). Zob. Andrzej Dziadzio, Der Code civil in der Rechtsprechung der Freien Stadt Krakau (1815-1846). Zwischen französischer und österreichischer Rechtskultur, „Beiträge zur Rechtsgeschichte Österreichs” 2020, Bd 2, s. 269-277. 
części”, np. umowę darowizny, zamiany, czy też - jak w kazusie Gajdzińskiego - sprzedaży ${ }^{146}$.

\section{Sprawa Chachulskiego przeciwko Golińskiemu}

W sprawie Franciszka Chachulskiego, zamieszkałego na Stradomiu pod L. 20 (obecnie ul. Stradomska 3) przeciwko sąsiadowi spod L. 21 (obecnie ul. Stradomska 1) Wincentemu Golińskiemu, Sąd Apelacyjny uchylił wyrok Trybunału, na podstawie którego przyznano Golińskiemu służebność okna wybitego w „murze środkowym" ${ }^{147}$. Zdaniem instancji odwoławczej Trybunał dopuścił się rażących uchybień, zarówno w ocenie stanu faktycznego, jak też w interpretacji KN. Po pierwsze, osnowa wyroku była przeciwna zeznaniom części świadków. Jeden z nich podważył zeznanie innego świadka (Krajewski), twierdząc, że upłynęło zaledwie pięć lat od czasu, kiedy Goliński wybił okno przy okazji remontu budynku. Inny świadek twierdził, że we wskazanym przez Golińskiego miejscu wcześniej nie było okna, zaś poprzedni właściciel domu L. 20 (Kępiński) nie zgodził się na jego wybicie. Po drugie, wyrok był też przeciwny rezultatom „obejrzenia sądowego”, gdyż zarówno biegli sądowi, jak też komisja budowniczo-policyjna stwierdziły, że wybicie okna nastąpiło bez planu, wobec czego Wydział Policji nakazał jego zamurowanie. Po trzecie, treść wyroku nie znajdowała oparcia w przedstawionych przez Golińskiego dokumentach, w tym akcie kupnasprzedaży kamienicy z 1819 r., które nie wspominały o służebności widoku. Sąd Apelacyjny dostrzegł też obrazę przepisów KN, w tym art. 688-689. Jak wspomniano, wprowadzał on podział na służebności istniejące w sposób ciągły, czyli bez konieczności działań ze strony człowieka (zbieg wód, ścieki, widoki) oraz służebności przerywane, przy których wymagane było działanie człowieka (prawo przechodu, branie wody, pastwisko). W art. 689 KN wyróżniał jeszcze służebności widoczne, „okazujące się przez zewnętrzne dzieła” (brama, okno, kanał) i niewidoczne, „nie mające znaku zewnętrznego" (zakazy: budowania na gruncie i budowania powyżej pewnej wysokości). Trybunał stwierdził, że służebność okna jest służebnością ciągłą i widoczną, możliwą do nabycia wskutek 30-letniego posiadania (zasiedzenie), ewentualnie ,przez tytuł” (art. 690 KN). Tymczasem w trak-

146 Zob. J. J. Delsol, Zasady.., s. 488-489. Sąd Apelacyjny uchylił wprowadzony przez Trybunał warunek, że rozstrzygnięcie sprawy nastąpi po wykonaniu zakreślonej przez sąd przysięgi.

${ }^{147}$ Plan miasta Krakowa..., s. 23 (oraz sekcja 57 - plan z identyfikacją adresów). 
cie procesu świadkowie zeznali, że otwór w murze został wykonany przed siedmiu laty; Goliński nie przedstawił też dokumentów nadających tytuł. Co więcej, art. $675 \mathrm{KN}$ zakazywał sąsiadowi, bez zgody drugiego, wybijania w murze środkowym okna lub innego otworu „w jakimkolwiek bądź sposobie”. Zaś zgodnie z art. $678 \mathrm{KN}$ zabronione było czynienie „widoków prostych" na „dziedzictwo sąsiada”, jeżeli odległość muru, w którym miały być wykonane, była mniejsza niż sześć stóp. Uchylając wyrok Trybunału, Sąd Apelacyjny nakazał Golińskiemu zamurowanie okna wychodzącego na tył domu pod L. 20, przyznając przeciwnikowi koszty prawne (30 złp $)^{148}$. W rozpoznaniu „,noty oppozycyjnej” Golińskiego Sąd Apelacyjny po wysłuchaniu stron i zapoznaniu się z pismami adwokatów uznał, że nie wnoszą one nic nowego do sprawy, czego konsekwencją było podtrzymanie wcześniejszego rozstrzygnięcia ${ }^{149}$.

\section{Sprawa Bzowskiego przeciwko Urasińskiemu}

Mieszkający na stałe w galicyjskim Gruszowcu (cyrkuł tarnowski) Kazimierz Bzowski był właścicielem kamienicy pod L. 459 w Krakowie (obecnie ul. św. Jana 4). W 1844 r. wytoczył powództwo przeciwko sąsiadowi Antoniemu Urasińskiemu, zamieszkałemu w domu przy Rynku Głównym pod L. 456 (obecnie Rynek Główny 40) ${ }^{150}$, domagając się wyburzenia (,zniesienia”) niedawno wzniesionego „bez jego wiedzy i zgody, nad dawny stan” muru granicznego między budynkami. Ponadto żądał zgody sądu na przywrócenie muru w poprzednim kształcie (o dawnej grubości i wysokości) na koszt Urasińskiego ${ }^{151}$.

${ }^{148}$ ANK, Archiwum Wolnego Miasta Krakowa, sygn. 29/200/1730, s. 993-996 (wyrok Sądu Apelacyjnego z 31 marca 1828 r.); s. 997-1004 („Wywód Uciążliwości ze strony Franciszka Chachulskiego przeciwko Wincentemu Golińskiemu”); wyrok Trybunału I Instancji z 4 października 1827 r.; reskrypt Wydziału Policji z 26 lipca 1820 r. nr 2787.

${ }^{149}$ Ibidem, s. 1707-1709 (wyrok Sądu Apelacyjnego z 20 maja 1828 r.). Zob. pisma w sprawie: s. 1711-1719 („Wywód Uciążliwości ze strony p. Wincentego Golińskiego przeciwko Franciszkowi Chachulskiemu”); s. 1725-1727 („Odpowiedź na Oppozycję Wincentego Golińskiego ze strony Franciszka Chachulskiego").

${ }^{150}$ Plan miasta Krakowa..., s. 18 (oraz sekcja 41 - plan z identyfikacją adresów).

151 ANK, Archiwum Wolnego Miasta Krakowa, sygn. 29/200/1842, s. 2363-2369 (,Wywód Rekursu ze strony Kazimierza Bzowskiego przeciwko Antoniemu Urasińskiemu”); s. 2355-2358 (wyrok Sądu Wyższego z 12 grudnia 1844 r.); uchwała Wydziału Spraw Wewnętrznych z 9 listopada 1840 r. nr 8061. Pełnomocnikiem Bzowskiego był Jan K. Rzesiński. 
Powództwo Bzowskiego dotyczyło też rekompensaty za straty poniesione wskutek wyburzenia starego muru, w tym ,zabrania” materiału budowlanego, który Urasiński zużył na budowę nowego muru (straty oszacowane na $3000 \mathrm{złp}$ ). Bzowski domagał się ponadto zapłaty 400 złp tytułem zadośćuczynienia za naruszenie prywatności („turbowanie posesji”) i zaśmiecenie posesji gruzem; 624 złp na pokrycie kosztów przejazdów do Krakowa (,w celu załatwiania tego interesu”); a także uiszczenia $450 \mathrm{złp}$ z tytułu trzyletniej ,utraty światła” i zawilgoceń budynku spowodowanych nowym obmurowaniem. Łącznie wynikłe z zatamowania światła i zawilgocenia domu roszczenia oszacował na kwotę 4472 złp, z oprocentowaniem sześć „od sta”, licząc od daty „,protokołu niepojednania” (13 grudnia 1843 r.). W 1847 r. do sprawy przypozwano Teofila Seiferta, z zawodu kupca, zamieszkałego w Rynku Głównym pod L. 21, który 22 października 1846 r. nabył kamienicę pod L. 456 (w 1843 r. sprzedano ją w drodze ,przymusowego wywłaszczenia", czyli licytacji). Obok przedmiotu głównego sądy badały ,punkt incydentalny” Seiferta, który domagał się „uwolnienia od toczącego się sporu", ponieważ nie był stroną sporu co do własności muru $^{152}$.

Sąd Wyższy uznał jego argumentację za nietrafną, gdyż spór ten został zgłoszony przez Bzowskiego jeszcze przed sprzedażą licytacyjną kamienicy L. 456 (1843) i dotyczył przede wszystkim praw rzeczowych, stąd też Seifert „nie mógł zostać uwolniony”. Sąd odrzucił również argument Seiferta, że po odbytej licytacji Bzowski nie zgłosił do hipoteki (nie wpisano ostrzeżenia hipotecznego) służebności ani wyłącznej własności muru. Nie poszukiwał on bowiem praw do kamienicy L. 456, lecz chciał jedynie odeprzeć ingerencję (,wdarcie się”) sąsiada w stanowiący jego własność mur tylny. Wykaz hipoteczny nie służył zaś do udowadniania wspólności, czy też „nieśrodkowości” muru. Prowadzone przez Urasińskiego prace remontowe polegające na podwyższeniu muru nie były dowodem na jego współwłasność. Możność nabycia na podstawie art. $661 \mathrm{KN}^{153}$ „,prawa środkowości, czyli wspólno-

${ }^{152}$ Ibidem, sygn. 29/200/1846, s. 1313-1315 („Punkt Incydentalny ze strony Teofila Seiferta kupca i obywatela Miasta Krakowa jako nowonabywcy kamienicy w Rynku pod L. 456 stojącey przeciwko Kazimierzowi Bzowskiemu”); s. 1341-1343 („Odpowiedź z strony Kazimierza Bzowskiego na Punkt Incydentalny ze strony Teofila Seiferta"). Pełnomocnikiem Seiferta był S. Boguński.

${ }^{153}$ Art. 661: „Każdy właściciel przystawiający do muru sąsiada może go zrobić środkowym, w całości albo w części, wracając właścicielowi muru połowę jego wartości albo 
ści muru wyłączną własność sąsiedzką stanowiącego" była uzależniona od spełnienia określonych w tymże artykule warunków, czego Urasiński nie tylko nie udowodnił, ,ale nawet nie twierdził”. Poza tym, prowadzone przez niego prace zwiększały użyteczność kamienicy L. 456, więc nie mogły być obojętne Seifertowi w kontekście roszczeń Bzowskiego; wręcz przeciwnie, on i Urasiński mieli prawo ,przytaczania wszelkich okoliczności mylność twierdzeń Bzowskiego, a istotną rzeczywistość wykazać zdolnych”; interes prawny Seiferta był tym bardziej widoczny, że był on aktualnym właścicielem kamienicy (Urasińskiego „wyzuto z własności”). Bezzasadne były też twierdzenia Seiferta, że Bzowski nie może żądać przyznania wyłącznej własności muru, gdyż przy sporządzaniu ,planu klasyfikacji sumy szacunkowej” uzyskanej ze sprzedanej kamienicy ,został oddalony ze swoją pretensją”. Sąd uznał, że „plan klasyfikacji” jedynie ,porządkuje prawa wierzycieli będące w wykazie hipotecznym", dotyczące sprzedanej nieruchomości, ale „nieutrzymanie się z zabezpieczeniem szkód wyrządzonych przez poprzedniego właściciela nie jest oddaleniem" i nie pozbawia możliwości dochodzenia własności oraz wynagrodzenia szkód „,na innej drodze”. Sąd dodał, że w razie nieudowodnienia przez Bzowskiego wyłącznych praw do muru, Seifertowi i Urasińskiemu będzie przysługiwało roszczenie o przyznanie wspólności muru oraz zabezpieczenie hipoteczne służebności „,na wieczne czasy", a także zwrot kosztów od strony przegrywającej spór. Z powyższych względów Sąd Wyższy uznał Seiferta za „przynależnego do sporu”154.

W przedmiocie głównym Sąd Wyższy oddalił roszczenia Bzowskiego obejmujące zgodę na wyburzenie nielegalnego muru i zapłacenie przez sąsiada 400 złp + 624 złp, gdyż w tych kwestiach zapadły już dwa zgodne wyroki Trybunału (z przyczyn formalnych „odwołanie się w drodze rekursu było niewłaściwe"). Sąd Wyższy pochylił się także nad sprawą kluczową, mianowicie ustaleniem, czy mur jest własnością Bzowskiego, czy też należy go uznać za ,środkowy”. Ponieważ na tym etapie postępowania strony niczego nie wykazały, sąd zatwierdził wyrok Trybunału dopuszczający (na podstawie art. $1348 \mathrm{KN}$ ) dowód ze świadków, którzy przy pomocy określo-

połowę wartości części, którą chce mieć środkową, i połowę wartości gruntu, na którym mur jest postawiony".

${ }^{154}$ ANK, Archiwum Wolnego Miasta Krakowa, sygn. 29/200/1846, s. 1295-1297 (wyrok Sądu Wyższego z 8 lipca 1847 r.); Wyroki Trybunału I Instancji: z 22 lutego 1844 r. (wydany w pierwszej instancji); z 23 lipca 1844 r. (zaoczny), z 21 października 1845 r. (oczny, wydany w drugiej instancji). 
nej roty przysięgi mieli potwierdzić, że mur należy do Bzowskiego, wskazując „na jakich zasadach twierdzenie swoje opierają”. Zdaniem Bzowskiego na ,środkowość” wskazywały przymocowane do muru od strony kamienicy L. 456 ,ganki i kloaki”; widoczny był także ściek od strony domu L. 459. Za niedopuszczalną uznał za to sąd wnioskowaną przez Bzowskiego ,inkwizycję ze świadków", którzy mieli potwierdzić, że zburzony mur był w dobrym stanie, co czyniłoby wiarygodnymi żądania odszkodowawcze Bzowskiego. Niemożliwe było też posiłkowanie się przezeń protokołem komisji budowlanej z 4 września 1844 r. oraz reskryptem Wydziału Spraw Wewnętrznych z 6 października 1844 r. W kwestii ostatniej, czyli żądania obniżenia wystawionego muru o jedną stopę i sześć cali, a także dokonania przez biegłych oceny, jakie są koszty szkód wyrządzonych podwyższeniem, Sąd Wyższy uznał owe roszczenia za zgłoszone przedwcześnie, gdyż odpowiedź na zakreślone pytania była uzależniona od ustalenia, czyją własnością jest mur graniczny ${ }^{155}$.

Sąd Wyższy rozstrzygnął sprawę w 1848 r. W pierwszej kolejności zajął się kwestiami incydentalnymi, w tym zarzutami wobec jednego ze świadków, Michała Służewskiego. Podtrzymał przy tym jeden z wyroków Trybunału, mocą którego uchylono zeznania Służewskiego. Powodem był fakt, że jego żona była stryjeczną siostrą Bzowskiego. Ponieważ zbyt bliskie pokrewieństwo było ewidentne (art. $283 \mathrm{KPC}$ ), na podstawie art. $291 \mathrm{KPC}$ jego zeznania uznano za „nie mające wpływu na orzeczenie”. Odnośnie do kluczowej kwestii własności muru należy wskazać, że podczas przesłuchania świadków - którzy zresztą nie potwierdzili własności którejkolwiek ze stron - okazało się, że pomiędzy kamienicami ,egzystowały” w istocie dwa mury „nieco różnej wysokości” (mur przynależny do L. 459 był niższy, „bo jedynie do I piętra”), „rumowiskiem pośrodku przesypane”156. Dla sądu był to dowód na „wspólność” tego „nietypowego”, dwuczłonowego muru, po-

${ }^{155}$ Ibidem s. 1298-1300 (wyrok Sądu Wyższego z 8 lipca 1847 r.); wyrok Trybunału I Instancji z 21 października 1845 r. Pozostałe pisma: s. 1301-1312 („Wywód Uciążliwości z strony Kazimierza Bzowskiego przeciwko Antoniemu Urasińskiemu”); s. 1317-1330 („Odpowiedź Antoniego Urasińskiego i Teofila Seiferta na ten wypadek, gdyby nie został uwolniony od sporu na rekurs Kazimierza Bzowskiego”); s. 1333-1337 („Rekurs wzajemny Antoniego Urasińskiego i Teofila Seiferta na ten wypadek, gdyby nie został uwolniony od sporu przeciwko Kazimierzowi Bzowskiemu”); s. 1345-1347 („Odpowiedź z strony Kazimierza Bzowskiego przeciwko Antoniemu Urasińskiemu i Teofilowi Seifertowi”).

${ }^{156}$ Ibidem, sygn. 29/200/1847, s. 1596-1597 („Wywód Rekursu z strony Kazimierza Bzowskiego przeciwko Antoniemu Urasińskiemu i Teofilowi Seifert”). Oprócz M. Służew- 
mimo że Bzowski dowodził, iż należałoby uwzględnić fakt zainstalowania przezeń nad murem ,daszku ze ściekiem na podwórze L. 459” i jego pokrycia gontem, co wskazywało na wyłączną własność Bzowskiego (art. 654 $\mathrm{KN})^{157}$.

Ostatecznie doszło do zatwierdzenia przez Sąd Wyższy wyroków Trybunału i oddalenia roszczenia Bzowskiego dotyczącego wyburzenia muru i jego wystawienia od nowa. Sąd uznał tym samym, że Urasiński miał prawo do podwyższenia muru środkowego na podstawie art. $658 \mathrm{KN}$. Kwestię żądań finansowych Bzowskiego (4 474 złp) sąd rozpatrywał dwuetapowo: w pierwszej kolejności uznał za prawomocne oddalenie (wyrokiem Trybunału z 21 października 1845 r.) żądania 400 złp za „turbowanie posesji” i 624 złp za przejazdy (rekurs uznał za nieprzyjmowalny Sąd Wyższy wyrokiem z 8 lipca 1847 r.); odnośnie do 3000 złp za zburzenie muru i użycie materiału oraz 450 złp za utratę światła i zawilgocenie - również oddalono roszczenia Bzowskiego dotyczące wyburzenia, co było konsekwencją oddalenia jego sprawy w kategorii „stwierdzenia własności”. Zarazem sąd oddalił żądania Urasińskiego i Seiferta dotyczące zwrotu połowy wartości muru (art. $661 \mathrm{KN}$ ), gdyż „nie usprawiedliwili oni żądania”"158.

\section{Sprawa Okońskiego przeciwko Senderkowskim}

W licznych sprawach, które można zakwalifikować jako posesoryjne, rola sądów ograniczała się do przywrócenia spokojnego posiadania. Tytułem przykładu można wskazać spór pomiędzy Michałem Okońskim, właści-

skiego świadkami byli Józef Kremer, Jan Chmielewski i Paweł Kochanowski, których przesłuchano „w dowodzie i odwodzie”.

${ }^{157}$ Urasiński nie mógł go więc wyburzyć i wystawić na nowo, ani też podwyższać, dlatego winien zwrócić połowę wartości muru. W przypadku wątpliwości co do relacji części świadków sąd powinien ,rozstrzygnąć na podstawie Kodeksu Napoleona”, że były dwa mury, z czego jeden - pokryty gontem przez Bzowskiego. Wyrokiem z 27 czerwca 1848 r. Trybunał I Instancji dyskusyjnie uznał też, na co zwrócił uwagę pełnomocnik Bzowskiego, że przeprowadzona ,inkwizycja ze świadków” w części dotyczącej zeznań o istnieniu dwóch murów nie może być podstawą wyrokowania, gdyż świadkowie mogą jedynie odpowiadać na pytania ustalone przez sąd, a nie „otwierać swoje zdanie - nie są bowiem biegłymi”.

${ }^{158}$ Ibidem, sygn. 29/200/1847, s. 1585-1589 (wyrok Sądu Wyższego z 19 października 1848 r.); Wyroki Trybunału I Instancji z 27 czerwca i 21 października 1848 r. Sąd przyznał im koszty sądowe. Pozostałe pisma: s. 1601-1604 („Odpowiedź Antoniego Urasińskiego i Teofila Seiferta na Rekurs Kazimierza Bzowskiego”); s. 1605-1607 („Konkluzja Incydentalna Antoniego Urasińskiego i Teofila Seiferta przeciwko Kazimierzowi Bzowskiemu”). 
cielem kamienicy pod L. 93 i 94 na Kazimierzu chrześcijańskim, a sukcesorami Stanisława Senderkowskiego, właścicielami domu pod L. 95 (obecnie wszystkie wymienione to jedna nieruchomość przy ul. Krakowskiej 12 lub 14) ${ }^{159}$. Okoński domagał się od sąsiadów zamurowania okna w murze kamienicy pod L. 94. Sąd Apelacyjny w swoim wyroku stwierdził, że w sprawach tego rodzaju działania sądu pokoju powinny się ograniczyć do ustalenia, że skargę posesoryjną wniesiono $\mathrm{w}$ terminie rocznym od chwili naruszenia posiadania. Źródłem wiedzy dla sędziego pokoju powinna być „inkwizycja bądź wyznanie stron". Zarazem niedopuszczalne były jakiekolwiek ustalenia $\mathrm{w}$ przedmiocie własności, gdyż należało to do procesu petytoryjnego (zakaz „wdawania się w kwestię zasady prawa, należącej do petitorio”). Jak wspomniano, kompetencje sądów pokoju określono zaś ustawą z $1825 \mathrm{r}$. (zob. przyp. 44, 47). Zresztą w omawianym kazusie sukcesorzy Senderkowskiego nie negowali faktu wybicia okna, więc stawiany przez Okońskiego wniosek dotyczący przeprowadzenia ,przy inkwizycji” dowodu ze świadków był zbyteczny. Sąd Apelacyjny podtrzymał wyrok sądu pokoju nakazujący im zamurowanie wybitego okna, gdyż z przedstawionej dokumentacji nie wynikało, aby plac między kamienicami pod L. 94 i 95 był własnością którejkolwiek ze stron ${ }^{160}$. Z drugiej strony, wziął pod uwagę twierdzenie Okońskiego, że sąd pokoju rozpatrywał też ,prawo nie należące do sporu”, czyli kwestie własnościowe ${ }^{161}$.

\section{Sprawa Pufelesa przeciwko Hartnerowi}

Kompetencji sądów pokoju dotyczyła także sprawa Peretza Pufelesa, zamieszkałego na Kazimierzu L. 107 (obecnie ul. Józefa 18) ${ }^{162}$, którego pełnomocnikiem był F. Słotwiński, przeciwko Leiblowi Hartnerowi, zamieszkałemu tamże, reprezentowanemu przez Józefa Jankowskiego, o zabronienie Pufelesowi dalszej przebudowy piętra domu i utrzymanie Hartnera w spokojnym posiadaniu. Sąd Apelacyjny stwierdził, że Pufeles nie przedstawił

${ }^{159}$ Plan miasta Krakowa..., s. 24-25 (oraz sekcja 57 - plan z identyfikacją adresów).

${ }^{160}$ ANK, Archiwum Wolnego Miasta Krakowa, sygn. 29/200/1758, s. 121-124 (wyrok Sądu Apelacyjnego z 13 sierpnia 1837 r.); wyrok sądu pokoju okręgu II z 23 marca 1836 r. Koszty sporu zasądzono Okońskiemu (16 złp + 42 złp).

${ }^{161}$ Ibidem s. 125-126 („Appellacja incydentalna Okońskiego”). Okoński zarzucał ponadto, że sąd pokoju wdał się w rozpoznawanie kwestii prawa własności, wbrew treści wyroków, wykazowi hipotecznemu i reskryptowi Senatu Rządzącego.

${ }^{162}$ Plan miasta Krakowa..., s. 25 (oraz sekcja 57 - plan z identyfikacją adresów). 
wykazu hipotecznego jako dowodu, że jest współwłaścicielem muru na pierwszym piętrze, i że służy mu prawo stawiania drugiego piętra $\mathrm{w}$ tejże kamienicy. Doszło więc do uchylenia opozycji i zatwierdzenia wyroku sądu pokoju zabraniającego dalszych prac budowlanych na drugim piętrze i utrzymującego Hartnera w spokojnym posiadaniu ${ }^{163}$.

Pełnomocnik Pufelesa przekonywał, że wcześniejszym wyrokiem Sądu Apelacyjnego uchylony został rekurs od wyroku sądu pokoju w przedmiocie zakazu dalszej przebudowy. Przy stawianiu nowych murów Pufeles chciał się bowiem oprzeć na fundamentach starych „murów głównych”, a także posadowić nowy dach - na całym domu; zarazem, odmawiał wynagrodzenia sąsiadowi kosztów udostępnienia fundamentów ${ }^{164}$.

Adwokat Hartnera dowodził, że art. $658 \mathrm{KN}$ nie znajduje w tym przypadku zastosowania, gdyż Pufeles nie wykazał, że jest współwłaścicielem murów pierwszego piętra (dlatego nie mógł ich też podwyższać). Konstrukcja Pufelesa została wybudowana z miękkiego materiału i zajmowała jedynie 1/5 części obwodu pierwszego piętra, dlatego przed rozpoczęciem prac budowlanych powinien on uzyskać zgodę współwłaścicieli (Hartner, Funkelstein). Wymuszał to nie tylko KN, ale także rezolucje Senatu Rządzącego (względy techniczne). Wprawdzie Funkelstein ,nie wchodził do sprawy”, ale w tej materii miał ,prawo interwencji”, gdyż planowana przez Pufelesa przebudowa drugiego piętra mogła spowodować poważne szkody. Hartner udał się po ochronę posesoryjną, którą uzyskał w sądzie pokoju ${ }^{165}$.

Pełnomocnik Pufelesa negował twierdzenia Jankowskiego, gdyż zgodnie $\mathrm{z}$ art. $658 \mathrm{KN}$ każdemu współwłaścicielowi służyło prawo wznoszenia drugiego piętra; Pufeles był właścicielem na podstawie wyroku z 1798 r., zaś fakt ograniczenia go w prawie własności nie został udowodniony ${ }^{166}$.

${ }^{163}$ ANK, Archiwum Wolnego Miasta Krakowa, sygn. 29/200/1739, s. 819-821 (wyrok Sądu Apelacyjnego z 30 listopada 1830 r.); wyrok sądu pokoju z 1 września 1824 r. Wpływ na orzeczenie miał spór o własność II piętra toczący się między Pufelesem a Jakubem Funkelsteinem.

${ }^{164}$ Ibidem, s. 823-824 („Notta oppozycyjna ze strony starozakonnego Peretza Pufelesa przeciwko Leiblowi Hartner" z 30 lipca 1828 r.); ibidem, sygn. 29/200/1731, s. 523-525 (wyrok Sądu Apelacyjnego z 8 lipca 1828 r.).

${ }^{165}$ Ibidem, sygn. 29/200/1739, s. 827-829 („Odpowiedź ze strony Leibla Hartnera na Oppozycję Pufelesa”). Fakt sporu między Pufelesem a Funkelsteinem o własność II piętra został uwzględniony w procesie posesoryjnym.

${ }^{166}$ Ibidem, s. 823-824 (,Notta oppozycyjna ze strony starozakonnego Peretza Pufelesa przeciwko Leiblowi Hartner" z 30 lipca 1828 r.). Twierdził ponadto, że Funkelstein nie 
* $\quad * \quad *$

Przeprowadzona analiza licznych archiwaliów pozwala wyciągnąć kilka wniosków ogólnych na temat stosowania przepisów KN przez sędziów Wolnego Miasta Krakowa w obszarze służebności gruntowych miejskich. Przede wszystkim zwraca uwagę niewystępowanie w przebadanych księgach sądowych kilku rodzajów służebności, w tym wydawałoby się dość oczywistych w warunkach dużego miasta: obowiązku przyjmowania wód spływających z gruntów wyższych - przez niżej położone (art. 640-645 KN); służebności rowu środkowego (art. 666-669 KN) i ogrodzeń środkowych (art. 670-673 $\mathrm{KN}$ ); oraz domu wspólnego (art. 664-665 KN), która dotyczyła zasad prowadzenia remontów i przebudowy murów głównych, dachów i pięter domów stanowiących współwłasność kilku osób, a więc również sytuacji często spotykanych w stosunkach miejskich ${ }^{167}$.

W aktach Sądu Apelacyjnego (oraz wyższych instancji) nie udało się też odnaleźć materiałów, które dokumentowałyby zapadanie wyroków granicznych (,rozgraniczenia i grodzenie nieruchomości”, art. 646-648 $\mathrm{KN})^{168}$. Co ciekawe, w obliczu wielkiego pożaru Krakowa z 1850 r. ${ }^{169}$ nie znalazły też zastosowania przepisy określające zasady odbudowy spalonych domów ${ }^{170}$. Przeprowadzona kwerenda nie przyczyniła się też do odnalezie-

wchodził do sprawy; Hartner nie wykazał, aby poniósł jakiekolwiek straty wskutek działań Pufelesa; spór między nim a Funkelsteinem nie mógł wpływać na kwestie posesoryjne; wnosił o zasądzenie kosztów.

${ }^{167}$ Art. 664: „Gdy różne piętra jednego domu należą do różnych właścicieli, jeżeli tytuły własności nie urządzają sposobu czynienia napraw i postawienia na nowo, powinny te być wykonywane podług następujących przepisów: Koszty na mury główne i na dach podejmują wszyscy właściciele razem, każdy w stosunku wartości piętra, które do niego należy. Właściciel każdego piętra sam daje podłogę, po której chodzi. Właściciel pierwszego piętra daje schody, które do jego piętra prowadzą; właściciel drugiego piętra daje schody do niego od pierwszego piętra, i tak następnie".

${ }^{168}$ Wyjątek stanowi rozbudowana i ciągnąca się kilkanaście lat sprawa ,podworców kamienic dominikańskich", która zostanie omówiona w osobnym artykule. Zob. np. ANK, Archiwum Wolnego Miasta Krakowa, sygn. 29/200/1763, s. 1837-1840 (wyrok Sądu Apelacyjnego z 19 listopada 1839 r.).

169 Zob. Juliusz Demel, Pożar Krakowa 1850 r., „,Rocznik Krakowski” 1952 , t. 32, s. 61-96; idem, Stosunki gospodarcze i spoteczne Krakowa w latach 1846-1853, „Biblioteka Krakowska” nr 107, Kraków 1951, s. 66-74; Jan ina Bien iarzó wna, Jan M. Małecki, Dzieje Krakowa, t. 3: Kraków w latach 1796-1918, Kraków 1979, s. 194-198.

${ }^{170}$ J. J. Dels ol, Zasady.., s. 470. Wymagana była wówczas zgoda wszystkich współwłaścicieli. W razie sprzeciwu jednego z nich należało przeprowadzić dział sądowy lub 
nia śladu procesów w sprawach służebności ustawowych, które miałyby na celu „korzyść publiczną”"171.

Przechodząc do kwestii statystycznych, należy stwierdzić, że w trakcie poszukiwań archiwalnych natrafiono na jedną tylko sprawę, w której pojawia się, trochę ,przy okazji”, służebność przechodu (sprawa Majdrowiczowej, art. 681-685 KN). Na 14 przebadanych spraw aż w ośmiu obiektem rozważań sędziów była środkowość muru, zaś w dziewięciu pojawia się problematyka korzystania z prawa widoku; w dziewięciu kazusach sądy korzystały z rozmaitych dowodów (opinie biegłych, zeznania świadków, dokumenty urzędowe). W pięciu przypadkach sprawę wszczęto przed sądem pokoju (inna rzecz, czy zawsze było to poczynanie prawidłowe). Wydział Prawa Uniwersytetu Jagiellońskiego wydawał opinie w czterech sprawach, przy czym trzy orzeczenia miały charakter merytoryczny, jedna opinia okazała się, z przyczyn formalnych, zbędna. Wysiłki sędziów w przedmiocie interpretacji KN trudno ocenić jednoznacznie, a tym samym zweryfikować rozbieżność opinii na temat ich przygotowania merytorycznego do pełnienia funkcji zawodowych ${ }^{172}$.

Można zaryzykować stwierdzenie, że przeważało literalne odczytywanie przepisów. Dużą sprawnością intelektualną, niezłą orientacją w przepisach KN (przynajmniej w części dotyczącej służebności), a niekiedy swego rodzaju ,pomysłowością” wykazywali się także adwokaci jako profesjonalni reprezentanci stron procesowych ${ }^{173}$. Oceniając przydatność samego Kodeksu Napoleona w stosunku do potrzeb i oczekiwań mieszkańców Krakowa, wydaje się, że zawarte w nim regulacje dość dobrze spełniały swoją rolę. Pozwalały na przynajmniej częściowe łagodzenie sporów i konfliktów stanowiących nieodłączny element relacji sąsiedzkich - niezależnie od miejsca i czasu.

sprzedać grunt w drodze licytacji, a uzyskaną kwotę podzielić proporcjonalnie do udziałów we własności; współwłasność domu mogła być ustanowiona „niepodzielnie lub podzielnie i piętrami”.

${ }^{171} \mathrm{~W}$ przypadku Wolnego Miasta Krakowa w grę wchodziłaby jedynie korzyść Skarbu Publicznego.

${ }_{172}$ Mateusz Mataniak, The Judicial Circle in the Free City of Cracow (1815-1846), „Beiträge zur Rechtsgeschichte Österreichs” 2020, Bd 2, s. 325-332.

${ }^{173} \mathrm{O}$ adwokaturze zob. M. Mataniak, Urzędnicy..., s. 98-100. 


\section{BIBLIOGRAFIA}

\section{Źródła rękopiśmienne}

Archiwum Narodowe w Krakowie

Archiwum Wolnego Miasta Krakowa, sygn. 29/200/219, 29/200/1656, 29/200/1660, 29/200/1666, 29/200/1667, 29/200/1670, 29/200/1672, 29/200/1677, 29/200/1683, 29/200/1714, 29/200/1715, 29/200/1717, 29/200/1723, 29/200/1730, 29/200/1731, 29/200/1739, 29/200/1742, 29/200/1743, 29/200/1748, 29/200/1749, 29/200/1758, 29/200/1761, 29/200/1763, 29/200/1842, 29/200/1846, 29/200/1847, 29/200/1967, 29/200/1997, 29/200/2007, 29/200/2026.

Archiwum Uniwersytetu Jagiellońskiego, sygn. WP I 58, WP I 59.

\section{Druki urzędowe}

Dziennik Praw [Księstwa Warszawskiego], t. 3.

Dziennik Praw Rzeczypospolitey Krakowskiey 1823, 1825.

Dziennik Praw Wolnego Miasta Krakowa 1845.

\section{Komentarze}

Aubry Charles, Rau Frédéric-Charles: Cours de droit civil français d'après la méthode de Zachariae, t. 2. Paris: Librairie Marchal \& Billar, 1935.

Delsol Jean Jacques: Zasady Kodeksu Napoleona w zwiąku z nauka i jurysprudencja przedstawione, t. 1. Warszawa: Redakcja Biblioteki Umiejętności Prawnych, 1873.

Delvincourt Claude-Étienne: Cours de code civil, t. 1. Paris: Delestre-Boulage, 1824.

Demolombe Jean Charles: Cours do Code Napoléon: Traité des servitudes ou services fonciers, t. 1-2. Paris: Auguste Durand \& Hachette, 1855.

Marcadé Victor Napoléon: Cours élémentaire de droit civile, t. 2. Paris: Libraire de Jurisprudence de Cotillon, 1850.

Toullier Charles Bonaventure Marie: Droit civil français suivant l'ordre du Code Napoléon, ouvrage dans lequel on a tâché de réunir la théorie à la pratique, t. 3. Bruxelles: Aug. Wahlen et Comp., 1824.

\section{Opracowania}

Bieniarzówna Janina, Małecki Jan M.: Dzieje Krakowa. T. 3: Kraków w latach 1796-1918. Kraków: Wydawnictwo Literackie, 1979.

Demel Juliusz: Pożar Krakowa 1850 r. „Rocznik Krakowski” 1952, t. 32, s. 61-96.

Demel Juliusz: Stosunki gospodarcze i społeczne Krakowa w latach 1846-1853. Biblioteka Krakowska nr 107. Kraków: Towarzystwo Miłośników Historii i Zabytków Krakowa, 1951.

Dziadzio Andrzej: Der Code civil in der Rechtsprechung der Freien Stadt Krakau (18151846). Zwischen französischer und österreichischer Rechtskultur. ,Beiträge zur Rechtsgeschichte Österreichs" 2020, Bd 2, s. 269-277.

Dziadzio Andrzej: Opinie profesorów i doktorów Wydziału Prawa Uniwersytetu Jagiellońskiego jako źródto do badań nad stosowaniem Kodeksu Napoleona w Wolnym Mieście Krakowie. „Krakowskie Studia z Historii Państwa i Prawa” 2020, t. 13, z. 3, s. 303-319. 
Dziadzio Andrzej: Powszechna historia prawa. Warszawa: Państwowe Wydawnictwo Naukowe, 2009.

Dziadzio Andrzej: Udziat Wydziału Prawa Uniwersytetu Jagiellońskiego w stosowaniu Code civil w Wolnym Mieście Krakowie (1815-1833). W: Miasto i państwo na przestrzeni dziejów. Studium historyczno-prawne. Księga Jubileuszowa z okazji czterdziestopięciolecia pracy naukowej oraz 70. urodzin Profesora Tadeusza Maciejewskiego. Red. Michał Gałędek. Warszawa: Wydawnictwo C\&H Beck, 2020, s. 185-200.

Grodziski Stanisław: Wpływy „Code civil” oraz innych kodyfikacji napoleońskich na ziemiach polskich, cz. 1. „Czasopismo Prawno-Historyczne” 2005, t. 57, z. 2, s. 61-67.

Hube Karol: Prawo cywilne obowiązujące w Guberniach Królestwa Polskiego. Warszawa: Gebethner \& Wolff, 1877.

Kuryłowicz Marek, Wiliński Adam: Rzymskie prawo prywatne. Zarys wykładu. Zakamycze: Kantor Wydawniczy Zakamycze, 2002.

Litewski Wiesław: Rzymskie prawo prywatne. Warszawa: Wydawnictwa Prawnicze PWN, 1999.

Malec Dorota: Wpływy „Code Civil” oraz innych kodyfikacji napoleońskich na ziemiach polskich, cz. 2. „Czasopismo Prawno-Historyczne” 2005, t. 57, z. 2, s. 69-87.

Malec Dorota: Z dziejów prawa hipotecznego Wolnego Miasta Krakowa. „Czasopismo Prawno-Historyczne" 2004, t. 56, z. 1, s. 88-89.

Mataniak Mateusz: Rada Administracyjna Miasta Krakowa i Jego Okręgu (1846-1853). Biblioteka Krakowska nr 165. Kraków: Księgarnia Akademicka, Towarzystwo Miłośników Historii i Zabytków Krakowa, 2019.

Mataniak Mateusz: The Judicial Circle in the Free City of Cracow (1815-1846), „Beiträge zur Rechtsgeschichte Österreichs" 2020, Bd 2, s. 325-332.

Mataniak Mateusz: Urzędnicy sądowi Wolnego Miasta Krakowa (1815-1846) na tle zasad organizacji jego sadownictwa. Zarys problematyki. W: Dzieje biurokracji, t. 9. Red. Artur Górak, Julia Kukarina, Jacek Legieć. Lublin: Towarzystwo Nauki i Kultury „Libra", 2019, s. 63-103.

Osuchowski Wacław: Rzymskie prawo prywatne. Zarys wykładu. Warszawa: Państwowe Wydawnictwo Naukowe, 1988.

Pańków Stanisława: Archiwum Wolnego Miasta Krakowa. „Archeion” 1954, R. 22, s. 103-128.

Pauli Lesław: Prawa obce w Rzeczypospolitej Krakowskiej. „Zeszyty Naukowe Uniwersytetu Jagiellońskiego" 1982, t. 625, Prace Prawnicze, z. 97, s. 145-147.

Plan miasta Krakowa Ignacego Enderle z lat (1802-1805) 1807-1808 tak zwany Senacki wraz z wykazem realności miasta z początku XIX wieku. Wyd. Henryk Münch. Kraków: Muzeum Historyczne Miasta Krakowa, 1959.

Pomianowski Piotr Z.: Rozwód w XIX wieku na centralnych ziemiach polskich. Polityka stosowania Kodeksu Napoleona w latach 1808-1852. Warszawa: Wydawnictwo Campidoglio, 2018.

Rosner Anna: Pierwsze polskie ttumaczenia Kodeksu Napoleona. W: Katarzyna Sójka-Zielińska, Kodeks Napoleona. Historia i współczesność. Warszawa: Wydawnictwo Prawnicze Lexis-Nexis, 2008, s. 271-294. 
Sójka-Zielińska Katarzyna: Kodeks Napoleona. Historia i współczesność. Warszawa: Wydawnictwo Prawnicze Lexis-Nexis, 2008.

Sójka-Zielińska Katarzyna: Wielkie kodyfikacje cywilne. Historia i współczesność. Warszawa: Liber, 2009.

Uruszczak Wacław: Prawo francuskie w Rzeczypospolitej Krakowskiej (1815-1846). W: Szkice z dziejów ustroju i prawa. Red. Marcin Kwiecień, Marian Małecki. Kraków: Wydawnictwo Uniwersytetu Jagiellońskiego, 1997, s. 91-99.

AUTOR: Mateusz Mataniak - historyk prawa, doktor nauk prawnych Uniwersytetu Jagiellońskiego, zatrudniony w Pracowni Wydawnictw Źródłowych (Wydział Prawa i Administracji UJ); absolwent historii (Uniwersytet Pedagogiczny im. KEN w Krakowie); zainteresowania badawcze: prawo i administracja Wolnego Miasta Krakowa, Urząd Wojewódzki w Krakowie (1921-1939, 1945-1950); e-mail: mateusz.mataniak@uj.edu.pl

AUTHOR: Mateusz Mataniak - historian of law, doctor of legal studies of Jagiellonian University, employed in the Pracownia Wydawnictw Źrodłowych (Faculty of Law and Administration of Jagiellonian University); graduate of history (Pedagogical University of Krakow); research interests: law and administration of the Free City of Krakow, the Regional Authority in Krakow (1921-1939, 1945-1950); e-mail: mateusz.mataniak@uj.edu.pl 